\title{
Charlemagne's गJihād Revisited: Debating the Islamic Contribution to an Epochal Change in the History of Christianization
}

\author{
Daniel G. König*
}

In 2006, Yitzhak Hen published an article under the title »Charlemagne's Jihad«, proposing that Charlemagne's policy of forced conversion of the Saxons - the earliest combination of conquest and forced conversion in the history of Christianity - had actually been modelled on a typically >Islamic approach to other religious groups. Hen argued that Charlemagne's expedition to Zaragoza in 777-778 as well as his reception of Hispanic refugees such as Theodulf at court acquainted the Frankish king with this Islamic approach which was then duly applied to the Saxons. The primary aim of the article is to raise and - at least partially - answer questions that arise from Hen's hypothesis. The first part of the article is thus dedicated to questioning if Islam of the late eighth century had already developed a systematic approach to non-Muslim religions that could be adopted by external observers. Even if Islam had already developed clear principles of dealing with other religions in the period under investigation, it cannot be taken for granted that the Carolingians and their informants were aware of these principles. The second part of the article then examines what Charlemagne and his entourage could have known about the Muslim treatment of non-Muslims. Since Hen's entire argument hinges on specific passages of the Capitulatio de partibus Saxoniae which he defines as IIslamic, this part of the article also discusses if these passages clearly reflect Islamic influence or rather build on previous Christian methods of dealing with other religions and of promoting the expansion of Christianity. Against this backdrop, the conclusion takes into account the possible historical causes for the Carolingian merging of conquest and forced conversion.

Keywords: Charlemagne; Saxons; forced conversion; Islam; Islamic influence; cultural transfer; Carolingian-Umayyad relations; al-Andalus; Spanish March

Charlemagne's forced conversion of the Saxons represents a landmark in the late antique and early medieval process of Christianization. For the first time in the history of Christianity, the latter was imposed during an outright conquest. ${ }^{1}$

Religious coercion had, of course, already existed in the Roman Empire, even before Christianity became the official religion. In the middle of the third century, the emperors Decius and Valerian tried to force Christians to participate in the imperial cult, whereas Diocletian and Galerius launched a persecution of Manichaeans and Christians at the beginning of

* Correspondence details: Daniel G. König, Karl Jaspers Centre for Advanced Transcultural Studies, Voßstraße 2, Building 4400, room 020, 69115 Heidelberg, Germany, email: daniel.koenig@asia-europe.uni-heidelberg.de. 
the fourth century. ${ }^{2}$ A period of religious ambiguity after Constantine I's rise to power ended with the legal abolition of non-Christian cults by Theodosius I in the 380 s. In various sectors of society, this legal framework backed groups who took violent measures against religious non-conformists: the pogrom against the Jews of Minorca in 418 that resulted in the latter's mass conversion to Christianity as well as pope Leo's I campaign against the Manichaeans of Rome in the years 443-45 may serve as two examples. ${ }^{3}$ All these forms of religious coercion have one thing in common, however: they were directed against the empire's own subjects. Being in a rather defensive position in Late Antiquity, the Empire never seems to have sought to impose Christianity on extra-imperial populations by the means of warfare. ${ }^{4}$

Among post-Roman elites, Christianity spread mainly by missionary efforts: Gothic groups had been exposed to the preaching of Ulfilas and his disciples and ultimately adopted a form of Christianity during the process of settling within the imperial borders. This also applies to other warrior elites who took over rule in former provinces of the Roman Empire, including the Spanish Sueves, the Burgundians, and the Vandals. In one way or the other, these groups were exposed to Gothic proselytism and accordingly adopted the Gothic variant of so-called >Arianism $<,{ }^{5}$ which they maintained until they either succumbed to the religious influence of the local Romanized population - the case of the Burgundians and Visigoths - or were swallowed up by a larger polity professing the faith of Nicaea - the case of Vandal North Africa. The Franks, in turn, accepted the Nicaean faith directly, as did various Anglo-Saxon leaders, the latter addressed directly by missionaries sent by Pope Gregory I to the British Isles. Thanks to the establishment of monastic communities by itinerant peregri$n i$, Christianity was strengthened in all parts of the former Western Roman Empire in the course of the seventh century. ${ }^{6}$ Late Roman and post-Roman processes of Christianization often involved a certain degree of coercion: ruling elites generally adopted Christianity first and then contributed to enforcing its adoption among their less powerful peers as well as among the remaining recalcitrant subject populations. ${ }^{7}$ Notwithstanding, Christianity was never imposed by force of arms until the Saxons were forced to accept it as a consequence of what might be justifiably termed a conquest or even an annexation of their society at the hands of Frankish elites.

Scholarship has traditionally explained this new link between conquest and Christianization as an inner-Christian phenomenon. Specialists of the Carolingian period and of early medieval processes of Christianization thus pointed to the special circumstances of the Frankish conquest of Saxony. Continuous tensions between Franks and Saxons dating from a period preceding the rule of Charlemagne drove the latter to attempt the conquest of Saxony. In

4 The only exception to this rule may have been Constantine's victory against Gothic groups in the 330s which, according to Sokrates and Sozomenos, allegedly persuaded the defeated Goths to accept Christianity. See König, Bekehrungsmotive, 47, with further literature. Apart from the fact that the veracity of this account can be questioned, it is not really comparable to the Carolingian case: if at all, Constantine made religious use of a single victory. He neither annexed Gothic territory, nor systematically imposed a Christian ecclesiastical administration on the latter.

5 Cf. Schäferdiek, Gotisch-arianische Mission, 203-222; Schäferdiek, Anfänge des Christentums, 295-310.

6 Brown, Rise of Western Christendom, 3-234; Padberg, Christianisierung Europas im Mittelalter, 15-87; Fletcher, Conversion of Europe, 1-192; König, Bekehrungsmotive, 43-99.

7 Cf. Dumézil, Racines chrétiennes de l'Europe. 
this context, Christianization continued a missionary policy already implemented within the Frankish realm and vis-à-vis its Frisian neighbours, but also served as a tool to break Saxon independence and to impose the new Frankish administration. Particularly drastic measures such as the killing of Saxons in Verden or the punishments for religious transgressions as formulated in the Capitulatio de partibus Saxoniae were rated as brutal overreactions to Saxon assaults in 782 . They were interpreted as desperate decisions taken by a Frankish ruling elite exasperated by a war that, all in all, lasted almost three decades and was accompanied by parallel military engagements on all fronts of the Carolingian realm. ${ }^{8}$ The combination of conquest and forced conversion resulted from what various scholars summarily describe as the collaboration of a snew church and a snew< political system. ${ }^{9}$

This explanation recalls Carl Erdmann's effort to explain the emergence of the crusading idea by claiming that the synthesis of warrior elites and Christianity in Late Antiquity and the early Middle Ages contributed to a militarization of Christianity, an explanation nuanced by Friedrich Prinz and further developed by James Russell. ${ }^{10}$ Jan Assmann's hypotheses on the "price of monotheism", however, raised the question of whether the hitherto prevalent image of a Christian religion militarized due to its adoption by warrior elites idealizes the peaceful character of ancient and late antique Christianity. According to Assmann, recently backed by Philippe Buc, ${ }^{11}$ the clear distinction between true and false, characteristic of all monotheistic religions, is responsible, not only for what Assmann calls "the invention of paganism ", ${ }^{12}$ but also for various acts of violence committed by adherents to monotheistic religions in the name of religious truth. ${ }^{13}$ In this way, the previous responsibilities are reversed: the violent mentality of post-Roman warrior elites did not awaken the aggressive potential of Christianity; rather, thanks to Christianity's latent aggression, the military feats of a post-Roman warrior elite acquired a religious dimension: consequently, Charlemagne's conquest of Saxony was spelt out in the symbolic language of expansionist monotheistic universalism. ${ }^{14}$

In 2006, Yitzhak Hen introduced a radically new explanatory model to this discussion by proposing that Charlemagne's decision to convert the Saxons by force had actually been inspired by the king's encounter with Islam. ${ }^{15}$ According to Hen, Charlemagne became acquainted with the king with an Islamic system of subjecting other religious groups during his expedition to Spain in 777-778 he. Supported and counselled by Hispanic refugees to the Frankish realm such as Theodulf of Orléans, Charlemagne decided to convert the Saxons by force. This decision, Hen claims, was taken in 795, the year to which he redates the particularly harsh Capitulatio de partibus Saxoniae, ${ }^{16}$ a document assigned to the period 775-90

8 See, for example, Kahl, Karl der Große, 49-131; Padberg, Christianisierung Europas im Mittelalter, 89-97; Fletcher, Conversion of Europe, 194-222; Wood, Missionary Life, 58; Becher, Gewaltmission, 321-329.

9 Brown, Rise of Western Christendom, 275; Padberg, Christianisierung Europas im Mittelalter, 97; Fletcher, Conversion of Europe, 194-195, 215-216, 221-222.

10 Erdmann, Entstehung des Kreuzzuggedankens, 16-18. Further thoughts on this synthesis in Prinz, Klerus und Krieg im frühen Mittelalter; Russell, Germanization of Early Medieval Christianity, 212.

11 Buc, Holy War, Martyrdom, and Terror.

12 Assmann, Mosaic Distinction, 48-67.

13 Assmann, Mosaische Unterscheidung, 11.

14 On religion as a symbolic language, see Voegelin, Order and History, 1-12; applied to the late antique and early medieval context in König, Öffentlich religiöse Auseinandersetzungen, 30-44.

15 Hen, Charlemagne's Jihad, 33-52.

16 Hen, Charlemagne's Jihad, 38-40. 
by the editor Alfred Boretius, ${ }^{17}$ to the year 782 by traditional scholarship. ${ }^{18}$ In 795 , Alcuin, the principal opponent to Charlemagne's policy of forced conversion, was removed from the centre of power, thus leaving the floor to Theodulf who - consciously or unconsciously, this remains open - ushered in a new policy of forced conversion by following sIslamic principles of dealing with subjected peoples of other religion. Alcuin was only able to formulate his opposition to this new policy in writing, as various letters from the year 796 suggest, which were written to various influential courtiers as well as to the king himself. ${ }^{19}$ On this basis, Hen concludes:

The exceptional, brutal policy of the Capitulatio did not emerge ex nihilo; it was deeply rooted in the political as well as the religious ideology that characterized al-Andalus at the time. The fact that within less than two years from its publication [i.e. 795 $\mathrm{CE}$, according to Hen], the Capitulatio was replaced by the more lenient Capitulare Saxonicum, suggests that the new politico-religious notions embedded in it were indeed strange and did not accord with the main stream of Carolingian political thought. It was an alien concept that did not fit the Carolingian reality, and hence it was discarded without any qualms shortly after its faults were exposed by Alcuin. (...) It was the language of jihad, brought to the Frankish court by Spanish Christians who sought refuge in the Frankish kingdom, if not by Theodulf of Orléans himself. ${ }^{20}$

Thus, Hen introduced a new and far-reaching explanation to the discussion sketched out above. Thanks to what Hen terms a "migration of ideas", Islam had left its imprint on the spread of Christianity beyond the borders of the former Roman Empire. According to this explanatory model, neither the mentality of a warrior elite, nor the latent aggressive universalism of Christianity, but Islam has to be held responsible for the fact that the diffusion of Christianity acquired a new, hitherto unknown, violent dimension.

The primary aim of the present article is to raise and - at least partially - answer questions that arise from Hen's hypotheses and the premises they are built on. Hen seems to believe that Charlemagne's informants were able to present the king with a clear-cut description of how Muslims dealt with adherents of other religions. It is not self-evident, however, that Islam of the late eighth century had already developed a systematic approach to non-Muslim religions that could be adopted by external observers. The first part of the article is thus dedicated to a sketch of the scholarly debate on this subject as well as the principle features of the Arabic-Islamic subjection of non-Muslim societies in the western Mediterranean.

Even if Islam had already developed clear principles of dealing with other religions in the period under investigation, it cannot be taken for granted that the Carolingian elite was aware of these principles. Hen correctly suggests that the Carolingians knew much more about Muslim al-Andalus than is usually acknowledged, but neglects to define this knowledge in concrete terms. The second part of the article is thus dedicated to understanding what Charlemagne and his entourage could have known about the Muslim treatment of non-Muslims. Hen's entire argument hinges on specific passages of the Capitulatio de partibus Saxoniae, which he defines as clearly influenced by >Islamic thought. Consequently, this part of the article also discusses if these passages clearly reflect Islamic influence or rather build on previous Christian ways of dealing with other religions and of organizing and administrating Christianity. 


\section{The emergence of an Islamic system of religious hierarchization}

The idea that Islamic principles of dealing with adherents of other religions could inspire political decisions in neighbouring non-Muslim societies builds on the premise that, from the beginning of the Arabic-Islamic expansion onwards, the Muslims established a clear system of religious hierarchization in the societies they subjected. This system as well as the principles that governed it would have to be clearly and explicitly formulated, clearly implemented and thus clearly observable from the external point of view, not only of those non-Muslims affected by it, but also of non-Muslims otherwise uninvolved in the Islamic administration of multireligious communities who depended on second-hand information.

\section{The Muslim subjection of the Middle East and the so-called Pact of 'Umar}

Hen's description of this Islamic system is based on one primary source, the so-called Pact of 'Umar, as well as on secondary literature characterized by the quest of understanding the Islamic treatment of other religions from a systemic point of view. ${ }^{21}$ Some of this literature resorts to a moral critique that focuses exclusively on the system's disadvantages for non-Muslims. ${ }^{22}$ The literature's systemic approach does not deny, but tends to obscure that the Islamic legal system consists of a huge body of multiple and occasionally contradictory opinions that reacted to changing historical circumstances and thus evolved over the centuries. This applies, in particular, to the three centuries following the Arabic-Islamic expansion: in the seventh to ninth century, many legal opinions were formulated for the first time and only slowly became part of an increasingly systematized, but nonetheless pluralistic corpus of quasi-canonical juridical texts. ${ }^{23}$

Milka Levy-Rubin has demonstrated that Islamic legal opinions regarding the Muslim treatment of subjected non-Muslims have to be positioned within this process of legal evolution. As already emphasized by Albrecht Noth, the flexibility of early surrender agreements contributed to the middle- and long-term success of a process of expansion which allowed an Arab minority to take control over a region stretching from the Iberian Peninsula to Central Asia within approximately 120 years. ${ }^{24}$ The rights of the subjected populations were generally established, not primarily along religious lines, but with regards to the question if the population in question had been subjected to Muslim rule as a result of force ('anwatan) or by negotiated peace agreement (sulhan). Although the former variant elicited punitive actions such as enslavement, confiscations etc., the Muslim conquerors generally left the religious life of the subjected populations untouched. The conquered received a security guarantee (amān) in exchange for the payment of taxes (jizya, kharajj) ${ }^{25}$ and acquiesced to measures that ensured their loyalty to the new overlords. These procedures are reminiscent of post-conquest stipulations imposed on conquered populations by non-Muslims in the pre-Islamic period, e.g. Romans, Byzantines and Sassanids. It is thus questionable, if measures taken in the immediate aftermath of

21 Tritton, Caliphs and their non-Muslim Subjects; Dennet, Conversion and the Poll-Tax; Khadduri, War and Peace, 175202; Friedman, Freedom and Coercion in Islam. Among the works missing in Hen's article are Fattal, Statut légal des non-musulmans; Kallfelz, Nichtmuslimische Untertanen im Islam; Planhol, Minorités en Islam.

22 Ye'or, Dhimmi.

23 Cf. Schacht, Origins of Muhammadan Jurisprudence.

24 Noth, Der frühe Islam, 63-67. Also see Donner, Islamic Conquests. Kennedy, Great Arab Conquests, 34-65, rather stresses the early Muslims military prowess, religious dedication and fighting spirit.

25 These two kinds of taxes, the jizya usually referred to as poll tax, the kharäj as land-tax, were not yet clearly distinguised in the early years following the conquest, cf. Cahen, Djizya; Cahen, Kharādj. 
the Muslim conquest of a specific locality were necessarily based on a legal system or even a clear-cut conception of religious hierarchization..$^{26}$ Corresponding doubts are reinforced if one does not regard the expanding Muslims as a monolithic body of dogmatically streamlined fanatics following the call to military jih $\bar{a} d,{ }^{27}$ but as a militarized and religiously motivated but dogmatically still rather flexible monotheist reform movement. ${ }^{28}$

Depending on the circumstances that characterized the settlement of the new Muslim ruling elites in the conquered territories, different forms of cohabitation emerged. Muslim settlement took place in three major variants: (1) in places originally inhabited by non-Muslims and taken by force, Muslim dominance was fully established; (2) in places originally inhabited by non-Muslims but subjected peacefully, Muslim dominance was tempered by the necessity of respecting certain privileges of the subjected population agreed upon during the negotiations of surrender; (3) in newly founded military encampments (amșār), initially only populated by Arabs, Muslims were dominant numerically. However, in the centuries following their establishment, even these military camps were increasingly populated by non-Muslims. Thus, cohabitation and intensifying interaction confronted Muslims from the Arabian Peninsula with the modes of life and religious customs of various subjected societies and began to affect the legal framework characteristic of the respective situation of conquest: since Muslims were a minority living among a majority of non-Muslims in all conquered territories, they had to prevent the religious assimilation of the Muslim population into the surrounding non-Muslim environment. This provoked various legal debates concerning the rights of non-Muslims under Muslim rule, the necessity of respecting the original clauses of peace agreements, and ultimately led to the formulation of laws of segregation in the course of the eighth century. These seem to have been increasingly canonized in the late eighth and ninth century. ${ }^{29}$

The document known as the Pact of 'Umar has to be placed into this context. The Pact of 'Umar is often unreflectingly ascribed to the second caliph 'Umar b. al-Khațāa (ruled 13-23/634-44) and regarded as the prime normative text that defined the Muslim stance towards subjected non-Muslims for centuries to come. Careful study of the attested versions of the document has brought to light, however, that it can probably not be assigned to the early period of Muslim expansion, but has to be regarded as one among several products of the legal debates and the processes of legal systematization mentioned above, that increasingly gained importance in the course of the ninth century. ${ }^{30}$

The legal development sketched out above has mainly been reconstructed on the basis of source material produced in the Middle East, under Muslim control since about the middle of the seventh century. It would not be justified to generalize by automatically applying these findings to all territories under Muslim control. This holds particularly true for the Muslim West, which was brought under Muslim rule slightly later than the Middle East, North Africa

26 Levy-Rubin, Non-Muslims, 8-57. Cf. Noth, Verträge, 282-314.

27 See Tyan, Djihād, for a traditional and systemic appraoch, and Crone, Thought, 363-385, for a wider definition of this multifaceted concept.

28 Donner, Conquests, 28-51.

29 Levy-Rubin, Non-Muslims, 58-87. Cf. Noth, Abgrenzungsprobleme zwischen Muslimen und Nicht-Muslimen, 290-315; Cahen, Djizya, 559-562.

30 Levy-Rubin, Non-Muslims, 86-87; Cohen, What was the Pact of 'Umar, 100-157; Miller, From Catalogue to Codes to Canon. 
being subjected in the course of the seventh century, the Iberian Peninsula invaded in 711. Until around the middle of the ninth century, the Muslim West was dependent on various cultural imports, including legal traditions, from the Middle Eastern heartlands of Islam. ${ }^{31}$

Hen's assumption that the Carolingians received most of their knowledge about Islam from the Iberian Peninsula seems plausible: Carolingian relations with the Muslim Middle East amounted to one exchange of ambassadors with the Abbasid caliph al-Manșur under Pippin the Short around 768, another one with Hārūn al-Rashìd under Charlemagne around $800 \mathrm{CE}$ as well as some scarcely attested long-distance trade..$^{32}$ As will be shown shortly, Carolingian relations with al-Andalus were much more intense. Consequently, it is of utmost importance to understand the specificities of the situation of non-Muslims under Muslim rule in the Muslim West by providing an overview on the processes of subjection and religious hierarchization that affected the two population groups in contact with the Frankish sphere, i.e. North African Berbers and the Romanized population of the former Visigothic realm.

\section{The Muslim subjection of Berber North Africa}

Even if we accepted that the Carolingian elite could have drawn back on ıforeign inspiration to come to a decision on how to subject a neighbouring region, we have to acknowledge that the expanding Franks and the expanding Muslims did not necessarily face the same type of societies. In Saxony, the Carolingians had to deal with a society that we could define as agrarian, non-urbanized, nonliterate, polytheistic and with a rudimentary administration. If the Carolingian elite were in search for inspiration on how to deal with the Saxons at all, they would have needed a blueprint for dealing with tribally organized polytheistic societies. In and around the Mediterranean, the Muslims mainly encountered urban, literate and, in comparison, effectively administrated pluri-religious societies, and only very few groups that had not yet been fully integrated into the folds of Judaeo-Christian monotheism. The only significant and politically organized populations that had neither fully succumbed to Judaism nor to a Romanized form of Christianity were the so-called Berbers, various tribal societies that controlled the hinterland of the Romanized urban coastline of northwestern Africa.

Arabic-Islamic sources, all of them written at least one and a half centuries after the period of conquest, if not later, credit some Berber groups with having adopted Judaism prior to Islam, ${ }^{33}$ others with being Christian, ${ }^{34}$ others with being "unbelievers" (kuffär) ${ }^{35}$ or »Magians " ('alā dìn al-majüsiyya). ${ }^{36}$ Some sources, such as al-Balādhurìs (d. 279/892) history of

31 Cf. Makkī, Ensayo sobre las aportactiones orientales, 65-92; Dhū’n-Nūn Ṭāha, Importance des voyages scientifiques, 39-44; Peña Martín (ed.), Iraq y al-Andalus. For the economic dimension of this cultural reorientation of the Iberian Peninsula see Constable, Trade and Traders in Muslim Spain, 3-5.

32 McCormick, Pippin III, 221-241; Borgolte, Gesandtenaustausch; König, Arabic-Islamic Views of the Latin West, 198201.

33 E.g. Ibn Khaldūn (d. 808/1406), Tärīkh, ed. Zakkār and Shahāada, vol. 6, 140: »kāna ba'ḍ hā ulā’ al-Barbar dānū bi-dīn al-yahūdiyya«; further sources in Hirschfeld, Problem of Judaized Berbers, 313-339.

34 Ibn 'Abd al-Ḥakam (d. 257/871), Futūh Miṣr, ed. Torrey, 201, dealing with the "non-Arabs of Ifrìqiya ('ajam Ifriqqiya), speaks of "Berbers who pertained to the Christian religion as they did" (man aqäma alä l-nașräniyya ma'ahum min al-Barbar); also see Ibn Khaldūn, Tārīkh, ed. Zakkār and Shahāda, vol. 6, 140-141. The diffusion of Christianity among a few Berber groups in pre-Islamic times is also suggested by linguistic evidence. Kossmann, Arabic Influence on Northern Berber, 66-67, 71-72, 80-81, for example, pointed to the fact that Berber variants used in regions adjacent to the (former) Roman province of Africa use a term resembling the Latin 'Easter (pascha) to denominate the Islamic breaking of the fast of Ramadian (îd al-fitr).

35 Ibn 'Abd al-Ḥakam, Futūḥ Miṣr, ed. Torrey, 199: "qātala al-Barbar wa-hum kuffār«.

36 Ibn Khaldūn, Tärīkh, ed. Zakkār and Shahāāa, vol. 6, 142. 
the expansion, completely ignore the Berbers' pre-Islamic religion, describe their subjection mainly in military terms and point to the large number of Berber captives taken. ${ }^{37}$ Since it is not possible in this context to present and discuss the discrepancies of individual sources, we may content ourselves with reviewing the variants of submission documented in these sources.

After being obliged by the conqueror 'Amr b. al-Āṣ to pay a poll tax (al-jizya) of 13.000 dīnār, the Lawāta, i.e. religiously undefined Berber inhabitants of the Cyrenaica (Barqa), received the permission to pay this tax by handing over their children to the Arabs around $641 . .^{38}$ A certain Kusayla, credited with having led an alliance of Byzantines (al-Rüm) and Berbers against 'Uqba b. Năfi' in the early 680s, is either mentioned in the same context as Berbers defined as "unbelievers «, ${ }^{39}$ or identified as a Christian who converted to Islam at the invitation of the Muslim conqueror Abū l-Muhäjir, but apostatized later. ${ }^{40}$ The "queen of the Berbers" (malikat al-Barbar) called "the priestess" (al-kähina), who spearheaded the last wave of resistance against the Arab invaders at the end of the seventh century, is not associated with a specific cult by some, but credited with second sight and with swearing by what she defines as "my God" (wa-ilāhi $).{ }^{41}$ Others claim that she may have adhered to Judaism. ${ }^{42}$ When she foresees her own death in battle, she ensures that her two sons are sent to the appointed governor of the Maghreb, Hassān b. al-Nu mān, who takes them under his protection (wa-akhadha li-abnayhä bi-amānan), entrusting the elder son with leadership over a group of Berbers from the tribe of al-Butr. ${ }^{43}$ According to one source, Ḥassān bin al-Nu'mān

imposed the kharāj [i.e. the land tax] upon the non-Arabs of Ifrìqiya ('ajam Ifriqqiya) and whoever among the Berbers who pertained to the Christian religion as they did, most of the ordinary population being from the [tribe of] al-Barānis except for a few from [the tribe of] al-Butr. ${ }^{44}$

Others state that he only accepted the Berbers' surrender and conversion to Islam under the condition that they provided the Arabs with a specified number of warriors. ${ }^{45}$ Such a treatment of Berber groups is also ascribed to Mūsā b. Nuṣayr, who succeeded Ḥassān bin al-Nu'mānas as governor of Ifrīqiya, moved further westward and subjected various Berber groups at the beginning of the eighth century. Mūsā b. Nuṣayr appointed a certain Țāriq b. Ziyād over a host of Berbers and Arabs that initiated the invasion of the Iberian Peninsula in 711. ${ }^{46}$ On the topic of the conversion of the Berbers, Ibn Khaldūn (d. 808/1406) concludes:

37 Al-Balādhurī, Futūh al-buldān, ed. de Goeje, 224-231.

38 Ibn 'Abd al-Hakam, Futūḥ Miṣr, ed. Torrey, 170; al-Balādhurī, Futūḥ al-buldān, ed. de Goeje, $224-226$.

39 Ibn 'Abd al-Hakam, Futūh Miṣr, ed. Torrey, 198-200.

40 Ibn Khaldūn, Tārīkh, ed. Zakkār and Shahāda, vol. 6, 142.

41 Ibn 'Abd al-Hakam, Futūh Mișr, ed. Torrey, 201.

42 Ibn Khaldūn, Tārīkh, ed. Zakkār and Shahāda, vol. 6, 140. Cf. Hirschfeld, Problem of the Judaized Berbers, 317.

43 Ibn 'Abd al-Ḥakam, Futūḥ Miṣr, ed. Torrey, 201; Ibn Khaldūn, Tārīkh, ed. Zakkār and Shahāda, vol. 6, 143.

44 Ibn 'Abd al-Hakam, Futūh Miṣr, ed. Torrey, 201: "wa-waḍa'a al-kharāj 'alā 'ajam Ifrīqiya wa-'alā man aqāma ma'ahum 'alā l-nașrāniyya min al-Barbar wa-'āmatuhum min al-Barānis illā qalīlan min al-Butr«; trans. by the author. Almost identical in Ibn Khaldūn, Tärīkh, ed. Zakkār and Shahāda, vol. 6, 143.

45 Ibn 'Idhārī al-Marrākushī (d. after 712/1312-13), Al-Bayān al-mughrib, ed. Colin and Lévi-Provençal, vol. 1, 38; cf. Lévi-Provençal, Recit de la conquête, 41-42; Ibn Khaldūn, Tārīkh, ed. Zakkār and Shahāda, vol. 6, 143.

46 Ibn 'Idhārī, Al-Bayān al-mughrib, ed. Colin and Lévi-Provençal, vol. 1, 42; cf. Lévi-Provençal, Recit de la conquête, 41-42; Ibn Khaldūn, Tārīkh, ed. Zakkār and Shahāda, vol. 6, 144. 
The Berbers apostatized twelve times between Tripolis and Tanger, and their Islam did not become firm until Ṭāriq and Mūsā b. Nuṣayr crossed over to al-Andalus after the subjection of the Maghreb, and in the name of jiha $\bar{d}$ a great number of footsoldiers and leaders of the Berbers also crossed. They settled there from the conquest onwards, and, during this time, Islam became an integral part of the Maghreb and the Berbers complied to its rule, and the word of Islam became firmly entrenched among them, and they lost sight of apostasy. Then khärijism took root among them, and they embraced it, having received it from mobile Arabs who had been exposed to it in Iraq. So the number of their (sectarian) groups multiplied, and their ways branched out. ${ }^{47}$

In sum, Arabic-Islamic historiography suggests that most Berber groups subjected by the expanding Arabs were, in their majority, not treated as monotheists with the same rights as urban Romanized Christians, but rather as polytheists who were offered the two options of either battle or subjection and conversion. On this basis, scholarship has reconstructed a process of subjection that only enabled few Berber groups already adhering to a form of monotheism to retain a pre-Islamic religion. ${ }^{48}$ Notwithstanding, the abovementioned variants of submission show that the Arabs' treatment of the Berbers did not amount to the mechanistic application of religious principles, but seems to have been dictated by the Arabs' need for human resources: seemingly non-monotheist Lawàta were given the possibility of paying the poll tax in slaves, whereas most other Berber groups were integrated into the Muslim host immediately upon subjection. In due course, these Berber groups formed an important part of the troops that invaded the Iberian Peninsula in 711. However, the "ambiguity in their status as tribute-paying subjects and militant members of the community of their conquerors", as Michael Brett and Elisabeth Fentress put it, ${ }^{49}$ is one important factor that has to be held responsible for the outbreak of the great Berber revolt in the 740s, as well as the Berber endorsement of heretic forms of Islam such as kharijism in the late eighth and ninth centuries, all of which were characterized by a loosening of the tie between Arab ethnicity and religiously legitimized rule..$^{50}$ In view of the emergence of these ethno-regional manifestations of Islam, it seems too simple to claim with Maya Shatzmiller that "Berber conversion remained a sore point in Berber/Arab relations and in the Berber communal and national memory for many years. " ${ }^{51}$ Although the rapid process of formal conversion via military integration certainly did not lead to an immediate and profound Islamization of Berber groups, Berber resistance of the 740 s and later was not directed against Islam as such, but against Arab domination.

47 Ibn Khaldūn, Tārīkh, ed. Zakkār and Shahāda, vol. 6, 144: »inna l-Barbar irtaddū ithnatay 'ashrata marra min Ṭarābulus ilā Ṭanja, wa-lam yastaqirr islāmuhum ḥattā ajāza Ṭāriq wa-Mūsā bin Nuṣayr ilā l-Andalus ba'da dawkh al-Maghrib wa-ajāza ma'ahu kathīr min rijālāt al-Barbar umarā uhum bi-rasm al-jihād. fa-istaqarrū hunālik min ladan al-fath, fa-ḥayna idhin istaqarra al-islām bi-l-Maghrib wa-adh'ana al-Barbar li-ḥukmihi, wa-rasakhat fihim kalimat al-islām wa-tanāsū al-ridda. thumma nabaḍat fihim 'urūq al-khārijiyya fa-dānū bihā, wa-laqanūhā min al-'Arab al-nāqila miman sama'ahā bi-l-'Irāq. wa-ta'addadat țawā’ ifuhum wa-tasha "abat țuruquhā (...)«; trans. by the author.

48 Cf. Basset and Pellat, Berbers, 1178-1179; Brett, Arab Conquest, 505-522; Norris, Berbers in Arabic Literature, 4479; Abun-Nasr, History of the Maghrib, 26-42; Dhanun Taha, Muslim Conquest and Settlement, 55-83; Brett and Fentress, Berbers, 81-88; Rouighi, Berbers of the Arabs, 67-101.

49 Brett and Fentress, Berbers, 87.

50 Crone, Medieval Islamic Political Thought, 54-65.

51 Shatzmiller, Labour in the Medieval Islamic World, 338. 
The Muslim subjection of the Iberian Peninsula

The creators of al-Andalus did not have to deal with paganism anymore. The Visigothic realm of the seventh and early eighth centuries was certainly not effectively administrated, but featured a centralized form of government characterized by a very close cooperation between the royal elite and the church..$^{52}$ Some remnants of pre-Christian polytheism had probably survived several centuries of Christianization. ${ }^{53}$ However, Christian aggression in the decades preceding the Muslim invasion was primarily directed against Jews. ${ }^{54}$ In all probability, the invading Muslims encountered mainly Christians and Jews when they took over power after 711 .

A rapid evaluation of contemporary Latin-Christian chronicles and later Arabic-Islamic historiography produced in Muslim al-Andalus suggests, however, that the Muslim treatment of adherents to non-Muslim religions on the Iberian Peninsula evolved in a way that is comparable to the development reconstructed by Milka Levy-Rubin with regards to the Middle East. ${ }^{55}$

Both contemporary Latin-Christian as well as later Arabic-Islamic sources suggest that collaboration played an important role in facilitating the conquest. They mention several Christians and Jews of North African as well as of Iberian provenance who supported the Muslim advance in one way or another. ${ }^{56}$ The Muslim takeover of Iberian cities and territories seems to have taken place peacefully in some cases, but was characterized by violence in other cases: ${ }^{57}$ the Hispano-Latin Chronicle of 754 classifies the surrender agreement negotiated in connection with the conquest of Toledo around 93/712 as "an evil and fraudulent peace " (pace fraudifica male). ${ }^{58}$ According to the anonymous chronicle Akhbār majmü' $a$, the surrender agreement concluded after the violent conquest of Mérida in 94/713 stipulated that the possessions of all inhabitants who had died during the conquest or fled to the north together with the properties and valuables of the city's churches were to belong to the victorious Muslims. ${ }^{59}$ Evoking the terrors of the conquest of Zaragoza in 95/714, the Hispano-Latin Chronicle of 754 claims that

some of the cities that remained sued for peace under duress and, after persuading and mocking them with a certain craftiness, the Saracens granted their requests without delay ${ }^{60}$

Cf. King, Law and Society, 16-21; Anton, König und die Reichskonzilien, 257-281.

53 McKenna, Paganism and Pagan Survivals, 108-146.

54 König, Bekehrungsmotive, 405-413.

55 For a detailed analysis of the Muslim conquest and settlement of the Iberian Peninsula in the eighth century see Lévi- Provençal, Histoire de l'Espagne musulmane, vol 1; Chalmeta Gendrón, Invasión e islamización; Manzano Moreno, Conquistadores, emires y califas; and, from a perspective emphasizing literary criticism: Hernández Juberías, Península imaginaria; Clarke, Muslim Conquest of Iberia.

56 See König, Arabic-Islamic Views of the Latin West, 47 notes 143 and 144 for a list of sources.

57 Cf. Chalmeta Gendrón, Invasión e islamización, 206-213.

58 Continuatio hispana, § 70, ed. Mommsen, 353; trans. Wolf, Conquerors and Chroniclers, § 54, 132.

59 Akhbär majmū'a, ed./transl. Lafuente y Alcántara, 16 (AR), 29 (ES).

60 Continuatio hispana, ed. Mommsen, $\S 71$, 353: pacem nonnulle civitates, que residue erant, iam coacte proclamitant adque suadendo et inridendo astu quoddam, nec more, petita condonant; trans. Wolf, Conquerors and Chroniclers, § 54,133 . 
According to all extant versions as well as all references to the so-called Treaty of Tudmir , possibly concluded 96/715 with the Visigothic noble Theodemir/Tudmir, the Muslims guaranteed security and religious freedom to the Christian population of Orihuela, Baltana, Alicante, Mula, Villena, Lorca and Ello in exchange for the payment of specified taxes and the fulfillment of precautionary measures ensuring that the subjected population did not give shelter to potential enemies. ${ }^{61}$

The period of Andalusian governors (c. 715-56) saw the first steps at administrating the newly conquered territory. The Chronicle of 754 associates 'Abd al-'Azīz b. Mūsā (ruled c. 94-97/713-716) with the conclusion of the Treaty of Tudmir and the exaction of the earliest taxes. ${ }^{62}$ His successor al-Ḥurr b. 'Abd al-Raḥmān al-Thaqafi (ruled c. 97-100/716-719) is said to have sent judges through Spain, exacted taxes and given back possessions to Christians as to ensure fiscal revenues. ${ }^{63}$ The Chronicle of 754 attributes further fiscal measures as well as the distribution of booty to al-Samh b. Mālik al-Khawlānī (ruled c. 100-102/719-21) ${ }^{64}$ who, in the chronicle Akhbär majmü $a$, is credited with having systematically gathered information about the status of the different territorial acquisitions, i.e. the question if they had surrendered peacefully or had been taken by force ${ }^{65}$ His successor 'Anbasa b. Suhaym al-Kalbì (ruled c. 102-107/721-26), the Chronicle of 754 claims, then doubled the Christians' taxes. ${ }^{66}$ The following governor, Yahyā b. Salāma al-Kalbì (ruled c. 107-10/726-28), is criticized by the chronicler for having created unrest by restoring property to the Christians that had previously been held by Berbers and Arabs. ${ }^{67}$ The governor 'Abd al-Malik b. Qațan al-Fihrī (ruled c. 114-16/732-34) is criticized for having allowed his judges to exact too many taxes. ${ }^{68}$ His successor 'Uqba b. Hajjāj al-Salūlī (ruled c. 116-23/734-41) is presented as having enforced

61 The Treaty of Tudmìr is cited in the following sources: al-'Udhrī, Tarșì al-akhbār, ed. al-Ahwānī, 4; al-Himyarī, al-Raw d al-mițār, ed. 'Abbās, 132, trans. O'Callaghan, History of Medieval Spain, 94; al-Dabbī, Bughyät al-multamis, ed. Codera and Ribera, 259; trans. Constable (ed.), Medieval Iberia, 37-38. Moreover, it is mentioned in Continuatio hispana, ed. Mommsen, $\S 79,356$; regarded as an interpolation by Wolf, Conquerors and Chroniclers, $151 \mathrm{n}$. 180.The treaty is also mentioned in Akhbär majmūa a, ed./trans. Lafuente y Alcántara, 12-13 (AR), 26 (ES). In spite of all these references, the authenticity of the document is questioned by Molina, Tudmir, 584-585. However, the arrangement described in the sources is generally regarded as plausible by scholars, cf. Chalmeta Gendrón, Invasión e islamización, 121, 206-209; Manzano Moreno, Conquistadores, emires y califas, 43, 46, 53, 65, 67, 70, 106-109, 112, 117, 121, 143, 263, 265-267, 278, 454.

62 Continuatio hispana, ed. Mommsen, $\S 79,356$ : omnem Spaniam per annos tres sub censuario iugo pacificans; trans. Wolf, Conquerors and Chroniclers, § 59, 135 .

63 Continuatio hispana, ed. Mommsen, § 80, 356: Alaor per Spaniam lacertos iudicum mittit (...) Spaniam ulteriorem vectigalia censiendo conponens; $\S 81,356$ : resculas pacificas Christianis ob vectigalia thesauris publicis inferenda instaurat; trans. Wolf, Conquerors and Chroniclers, § 62, § 64, 136-137.

64 Continuatio hispana, ed. Mommsen, § 56, 358: ulteriorem vel citeriorem Iberiam proprio stilo ad vectigalia inferenda describit, preda et manualia vel quidquit illud est, quod olim predaviliter indivisum retemtabat. in Spania gens omnis Arabica sorte sociis dividendo partem ex omni re mobili et inmobili fisco adsociat; trans. Wolf, Conquerors and Chroniclers, § 69, 138.

65 Akhbār majmū'a, ed./transl. Lafuente y Alcántara, 23-24 (AR): »fa-waḍa áa yadan fỉ l-suwāl [sic] 'an al-'anwa li-yumayyizahu min al-șulh«, 35 (ES).

66 Continuatio hispana, ed. Mommsen, § 90, 359: vectigalia Christianis duplicata exagitans; trans. Wolf, Conquerors, $\S 74,140$.

67 Continuatio hispana, ed. Mommsen, § 92, 359: acri ingenio Ispanie Saracenos et Mauros pro pacificis rebus olim ablatis exagitat atque Christianis plura restaurat; trans. Wolf, Conquerors and Chroniclers, $\S 75,141$.

68 Continuatio hispana, ed. Mommsen, § 108, 362: Iudicesque eius prerepti cupiditate; trans. Wolf, Conquerors and Chroniclers, § 81, 146 . 
law and order, as having ordered a census to be taken of the entire population, as having systematically enriched the fisc and as having judged everyone according to his own law. ${ }^{69}$ The early 740 s were marked by a civil war brought about by the Berber uprising in al-Andalus and North Africa as well as the arrival of new Arab troops from Syria. According to the Chronicle of 754, the governor Abū l-Khațtāa al-Ḥuṣām b. Dirār al-Kalbī (ruled 125-27/743-45) unjustly demanded the payment of additional taxes from Athanagild, the son of the abovementioned Theodemir/Tudmir. In view of the recent arrival of Syrian forces, the sum of 27.000 solidi was produced within three days. Ibn al-Khatiib (d. 776/1375) claims that the distribution of the share of taxes to these newly arrived military units was effected by a certain Arțabās, defined in this context as "comes (qümis) of al-Andalus, leader of the non-Arabs under protection and exactor of their taxes for the amir-s of the Muslims ${ }^{70}{ }^{70}$ It is not clear, however, if Artabās already fulfilled this institutional function, not yet mentioned in the Chronicle of 754, during the governorship of Abū l-Khaț̣ār: according to Ibn al-Quițiyya (d. 367/977), Arțabās, son of the former Visigothic king Vitiza, was appointed qümis around a decade later under 'Abd al-Rahmān I (ruled 138-72/756-88). ${ }^{71}$ In any case, the effects of the civil war seemingly prompted the last Andalusian governor Yūsuf b. 'Abd al-Raḥmān al-Fihrī (ruled c. 129-38/746-56) to carry out a new population census and to erase the names of (deceased) Christian taxpayers from the public records. ${ }^{72}$

This list of activities, recorded in their majority by a contemporary Latin-Christian chronicler ${ }^{73}$ suggests that the Andalusian governors of the first half of the eighth century established a rudimentary fiscal system on the Iberian Peninsula. ${ }^{74}$ This fiscal system cannot be regarded as stable, however: even after the surrender status of each community had been assessed, the amount of taxes could vary from governor to governor, some of whom seem to have exploited the Christian subject population, while others protected their possessions. In addition, demographic factors resulting from the arrival of new groups and high mortality rates necessitated adapting the tax registers and the methods of distribution in use. Latin-Christian and Arabic-Islamic sources both suggest that the measures taken were characterized by a certain degree of flexibility necessary to ensure the regular flow of fiscal revenues in a situation of political instability. Even if we believe that the late period of governors witnessed the emergence of a quasi-institutional arrangement between conquerors and conquered, the latter represented by the quimis, the scant information at our disposal does not allow to verify how far the latter's influence extended into the subjected Christian society

69 Continuatio hispana, ed. Mommsen, $\S 109,362-363$ : descriptionem populi facere imperat atque exactionem tributi ardue agitat. perversos Spanie vel diversis vitiis implicatos ratibus adpositis maria transvolat, fiscum ex diversis occasionibus promptissime ditat, austerius et omni occulta datione perseverat; neminem nisi per iustitiam legis proprie damnat (...); trans. Wolf, Conquerors and Chroniclers, § 82, 146-147.

70 Ibn al-Khațīb, Al-Ihạța, ed. 'Inān, vol. 1, 103: "qūmis al-Andalus wa-zaīm 'ajam al-dhimma wa-mustakhrij kharājihim li-umarä’ al-muslimin"».

71 Ibn al-Qūṭiyya, Tārỉkh iftitāh al-Andalus, ed. al-Ibyārī, 58: »wa-walāhu al-qimāsa, fa-kāna awwal qawmas bi-lAndalus«; cf. Chalmeta Gendrón, Kūmis, 376.

72 Continuatio hispana, ed. Mommsen, $\S 131,366$ : iste descriptionem ad suggessionem residui populi facere imperat atque ut eos, quos ex Christianis vectigalibus per tantas eorum strages gladius iugulaverat, a publico codice scriniarii demerent licet peculando, sollicite imperat; trans. Wolf, Conquerors and Chroniclers, § 91, 156. On this chronicler see Cardelle de Hartmann, Textual Transmission of the Mozarabic Chronicle, 17-19. 
of the Iberian Peninsula, especially if we account for regional discrepancies brought about by different circumstances of conquest, varying settlement patterns and forms of regional and local rule. ${ }^{75}$

Since the extraction of fiscal resources from a recently subjected population is a common feature of probably every conquest, we must ask if the payment of taxes was explicitly understood as having a religious dimension by the affected population. The Chronicle of 754 , as cited above, defines the fiscal territory in geographical terms as Spania or Iberia, the taxpayers as Christiani. It thus suggests that the payment of taxes was in some way linked to the religion of the tax payers, especially considering that this collective term never appears in those parts of the chronicle that describe the Iberian Peninsula before the Muslim invasion. ${ }^{76}$ The fact that the subjected inhabitants of the Iberian Peninsula probably understood from an early period onwards that they paid taxes as Christians to non-Christian conquerors, ${ }^{77}$ does not allow us to infer that the Andalusian governors legitimized the fiscal system in religious terms vis-à-vis the subjected population or imposed a rigid system of explicitly formulated Islamic norms on the conquered society. Later Arabic-Islamic sources on this period use the terminology of dhimma, dhimmat Muhammad or even dhimmat Alläh, but do not all employ the term jizya, usually regarded as an essential feature of the Islamic system of religious (including fiscal) hierarchization. In general, these historiographical sources focus on the establishment of a link between the payment of taxes and resulting "protection" (dhimma), but do not dwell on the religious character or the religious justification of extracting fiscal resources. ${ }^{78}$

Whereas those involved and affected probably understood that the Muslim extraction of taxes from non-Muslim subjects was not only based on the dichotomy of conquerors and conquered, but also on their religious alterity, a legal system providing an explicit Islamic justification of this relationship does not seem to have existed under the rule of the Andalusian governors. Al-Khushanī (d. 371/981), author of a History of the Judges of Córdoba

75 Cf. Chalmeta Gendrón, Invasión e islamización, 157-60, 347-84; Manzano Moreno, Conquistadores, emires y califas, 121-188, 239-362.

76 The Continuatio hispana, ed. Mommsen, acknowledges that Muhammad was seen as a prophet (§ 12, 338: propheta eorum), refers to urbes Romanas $(\$ 15,339)$ in connection with Sisebut's subjection of Iberian cities held by the Byzantines, and generally defines the pre-Muslim Iberian Peninsula in geographical (Iberia, Hispania, Yberie, Spania, Spanii, cf.§ 15-16, 26, 36, 65, pages 339, 341, 351) or ethno-political terms, either speaking of the "realm of the Goths" or linking the ethnonym »Gothi« to the accession of a new king (regnum Gothorum, regnum Wisegothorum, reges Gothorum, Gothi, cf. §18-19, 21, 23, 26, 35, 46, 49, 53, 58, 67, 71, 74, pages 340-341, 343, 348-350, 352-354). "Christiani« are only mentioned in ecclesiastical contexts (§ 22, 340: Christianis mentibus; § 54, 350: multiplici Christianorum collegio clero). The only other ethnic term used for groups on the Iberian Peninsula is "Basques« (§ 36, 343: Vasconum).

77 In the case of the Chronicle of 754, the relative absence of information on the Muslim conquerors' religion has prompted Wolf, Conquerors and Chroniclers, 35-41, to believe that the chronicler deliberately avoided dealing with a topic that could have caused frictions with the Muslim authorities.

78 On the Qur'ānic term jizya, see Qur'ān 9:29. Cf. Cahen, Djizya, 559-562. The following sources all mention the concept of dhimma, linked to God and Muhammad, but not the term jizya: al-'Udhrī, Tarșī' al-akhbār, ed. alAhwānī, 4: "anna lahu 'ahd Allāh wa-mìthāquhu wa-mā ba atha bihi anbiyā uhu wa-rusuluhu, wa-anna lahu dhimmat Allāh 'azz wa-jall wa-dhimmat Muhammad (...).«; al-Ḥimyarī, al-Raw ạ al-mi țār, ed. 'Abbās, 133: »wa-inna lahu 'ahd Allāh wa-dhimmatuhu wa-dhimmat nabīhi (...).«; al-Ḍabbī, Bughyāt al-multamis, ed. Codera and Ribera, § 675, 259: »wa-inna lahu 'ahd Allāh wa-dhimmatuhu wa-dhimmat nabỉhi (...).« Ibn al-Khațỉb, al-Ihātạa, ed. 'Inān, vol. 1, 103, uses the terms dhimma and kharāj: »za îm 'ajam al-dhimma, wa-mustakhrij kharäjihim «, as well as »the riches of the non-Arab people under protection« (amwäl ahl al-dhimma min al-'ajam). 
(Tärìkh al-qudāt bi-Qurțuba), only knows three judges of Córdoba active in this period - i.e. Mahdī b. Muslim, 'Anțara b. Filāh and Muhājir b. Nawfal al-Qurāshī. In each case, however, he only provides rather superficial information on their activities. The earliest Andalusian judge, Mahdi b. Muslim, is said to have been appointed by the Andalusian governor 'Uqba b. Hajjaj al-Salüli (ruled c. 116-23/734-41), and also was mentioned by the Chronicle of 754 to have enforced the law. ${ }^{79}$ According to al-Khushani, the governor explained in detail to the newly appointed judge how he should carry out his office. This scatalogue of ethical behaviour ' does not refer to any source of legal authority except for the Qur'an, the sunna as well as undefined books, not yet to any legal school of thought. ${ }^{80}$ Although the authenticity of such a document may be doubted, it nonetheless proves that al-Khushani regarded the middle of the eighth century as a period in which the foundations of a legal system in al-Andalus were laid down. Al-Khushani treats the succeeding two judges superficially, and obviously did not dispose of much information. ${ }^{81}$ He proffers more details on Yahyā b. Yazīd al-Tüjibì, the judge of Córdoba witnessing the transition of power from the last Andalusian governor, Yūsuf b. 'Abd al-Raḥmān al-Fihrì (ruled c. 129-38/746-56), to the first Umayyad amìr, 'Abd al-Raḥmān I (ruled 138-72/756-88). Not even then, however, does he mention any involvement of this judge in the affairs of the subjected population. ${ }^{82}$

Although the increasingly systematic exaction of taxes and the appointment of judges in Córdoba clearly shows that Muslim al-Andalus in the period of the governors developed administrative mechanisms, a systematized legal system only seems to have been introduced in the second half of the eighth century, that is after the coup d'état and foundation of the emirate of al-Andalus at the hands of the Umayyad refugee 'Abd al-Rahmann I (ruled 138$72 / 756-88),{ }^{83}$ the latter credited, as we have seen, with the creation of an institutional mediator between the subjected population and the Muslim authorities. ${ }^{84}$ We should consider in this context, that - even in the Middle Eastern heartlands of Islam - the transition from oral legal traditions to what Joseph Schacht defined as »the literary period « of Islamic law only seems to have taken place in the second century of the hijra, i.e. the second half of the eighth century ${ }^{85}$ The earliest Middle Eastern authorities of Islamic law - i.e. Abū Hanīfa (d. 150/767), al-Awzāì (d. 157/774), Mālik b. Anas (d. 179/795), al-Shāfiī (d. 204/820), Aḥmad b. Hanbal (d. 241/855) - were active in the period around 750 that witnessed both the accession to power of the Carolingians and the Umayyads of al-Andalus. According to al-Khushanī, it was a certain Ziyād b. 'Abd al-Raḥmān, also known as Shabțūn (d. 193/809 or 199/815), who first introduced the legal sciences (al-figh) and the legal distinction between what is permitted and forbidden (al-ḥalāl wa-l-harām) to al-Andalus. ${ }^{86}$ Ibn al-Qūṭyya (d. 367/977) credits him and his contemporary al-Ghāzì b. Qays (d. 199/815) with the introduction of

79 Al-Khushanī, Kitāb al-quḍat ed./trans. Ribera, 18-23 (AR), 23-30 (ES). Cf. Continuatio hispana, ed. Mommsen, § 109, 362-363.

80 Al-Khushanī, Kitäb al-qudāt, ed./trans. Ribera, 19-23 (AR), 24-30 (ES), with references to the Qur'ān and the sunna on page 20 (AR), 24-25 (ES), to undefined books on page 23 (AR), 29 (ES).

81 Al-Khushanī, Kitāb al-quḍāt, ed./trans. Ribera, 23-27 (AR), 30-35 (ES).

82 Al-Khushanī, Kitāb al-qud̄àt, ed./trans. Ribera, 27-29 (AR), 35-37 (ES).

83 Fierro, Introduction of hadìth in al-Andalus, 73-74.

84 Ibn al-Qūṭiyya, Iftitāh al-Andalus, ed. al-Ibyārī, 58.

85 Schacht, Origins of Muhammadan Jurisprudence, 176-179.

86 Al-Khushanī, Kitāb al-qudāt, ed./trans. Ribera, 50 (AR), 61 (ES); cf. Fierro, Introduction of hadìth in al-Andalus, 73. 
Măliki law, specifically the latter's legal compilation al-Muwatta $a^{\prime}$, to al-Andalus. ${ }^{87}$ It is in this period, Ibn Hayyān (d. 469/1076) claims, that the legal school of al-Awza'î', described by Schacht as displaying a still rudimentary form of systematic reasoning, ${ }^{88}$ was sidelined by Máliki law, ${ }^{89}$ which then became firmly entrenched in the Umayyad emirate in the first half of the third/ninth century, ${ }^{90}$ more specifically during the reign of 'Abd al-Rahmann II (ruled 206-38/822-52). In the words of Eduardo Manzano Moreno:

In a moment that can be dated very approximatively to the emirate of 'Abd alRaḥmān II, Córdoba witnessed unprecedented efforts to import the principles of Muslim practices and norms from the Orient. At this moment one still cannot speak of a network of Andalusī 'ulama' as is evident from the fact that only a handful of Andalusī teachers can be ascribed to the period between the end of the eighth and the first decades of the ninth centuries (second-third century of the hijra). However, a hundred years having passed after the conquest, an enormous interest to become acquainted with the theoretical, practical and juridical foundations of Islam arises in al-Andalus. Over the years, this initial interest becomes a veritable torrent of people who engrossed themselves in religious knowledge. ${ }^{91}$

Manzano Moreno's evaluation is seconded by Janina M. Safran, according to whom the need to keep Muslims distinguishable from a non-Muslim majority in an increasingly organized polity and society of al-Andalus gave rise to the motivation to formulate clear legal principles defining the boundaries between Muslims and non-Muslims. ${ }^{92}$ Consequently, it comes as no surprise that explicit and concrete stipulations of how to deal with the subjected non-Muslim population including their, at least partially, religious justification, only become accessible in textual form in the Andalusian reading (riwāya) of of Mālikī law by Yahyā b. Yahyā al-Laythì (d. 234/848), a contemporary of 'Abd al-Raḥmān II. ${ }^{93}$ Referring to a directive by the Umayyad caliph 'Umar b. 'Abd al-'Azìz (ruled 99-101/717-20), negotiated surrender agreements, authoritative tradition (sunna) and more recent opinions of legal authorities, the text explains and justifies the relationship between conquerors and conquered in the following way:

Yahyyā related to me from Mālik that he had heard that 'Umar b.'Abd al-'Aziz wrote to his governors telling them to relieve any people who payed the jizya from paying the jizya if they became Muslims. Mălik said: »The sunna is that there is no jizya due from women or children of people of the Book, and that jizya is only taken from men who have reached puberty. The people of dhimma and the Magians do not have to pay any zakät on their palms or their vines or their crops or their livestock. This is because $z a k \bar{a} t$ is imposed on the Muslims to purify them and to be given back to their poor, whereas jizya is imposed on the people of the Book to humble them. As long as they are in the country they have agreed to live in, they do not have to pay anything on their property except the jizya. If, however, they trade in Muslim countries, coming and going in them, a tenth is taken from what they invest in such trade. This is because jizya is only imposed on them on conditions, which they have agreed on, namely that they

87 Ibn al-Qūṭyya, Tärīkh iftitāh al-Andalus, ed. al-Ibyārī, 56, 62; cf. Fierro, Introduction of hadīth in al-Andalus, 73.

88 Schacht, al-Awzaì. Cf. Watt and Cachia, History of Islamic Spain, 54-55, on the introduction and replacement of the madhhab of al-Awza î in al-Andalus.

89 Ibn Ḥayyān, al-Muqtabis [II-1], ed. Makkī, fol. 119b, 199-200; cf. Safran, Defining Boundaries in al-Andalus, 46.

90 Ibn al-Qūṭiyya, Tärìkh iftitāh al-Andalus, ed. al-Ibyārī, 63-64, 70; cf. Fierro, Introduction of hadīth in al-Andalus, 74.

91 Manzano Moreno, Conquistadores, emires y califas, 371, trans. by the author.

92 Safran, Defining Boundaries in al-Andalus, 35-80.

93 On Yahyā b. Laythī see Fierro, El Alfaquí Beréber, 269-344. 
will remain in their own countries, and that war will be waged for them on any enemy of theirs, and that if they then leave that land to go anywhere else to do business they will have to pay a tenth. Whoever among them does business with the people of Egypt, and then goes to Syria, and then does business with the people of Syria and then goes to Iraq and does business with them and then goes on to al-Madina, or Yemen, or other similar places, has to pay a tenth. People of the Book and Magians do not have to pay any zakāt on any of their property, livestock, produce or crops. The sunna still continues like that. They remain in the religion they were in, and they continue to do what they used to do. If in any one year they frequently come and go in Muslim countries then they have to pay a tenth every time they do so, since that is outside what they have agreed upon, and not one of the conditions stipulated for them. This is what I have seen the people of knowledge of our city doing. ${ }^{94}$

In sum, al-Andalus of the eighth and ninth centuries went through a process of legal systematization that is comparable to the one described by Milka Levy-Rubin for the Middle East of the seventh and eighth centuries. In the last quarter of the eighth century,i.e. the time when Charlemagne was occupied with the conquest of Saxony, a clear-cut Islamic system of dealing with non-Muslims laid down in canonical texts did not exist on the Iberian Peninsula. From this point of view, Hen's assumption that the Carolingian court of the late eighth century could have been inspired by an explicitly formulated Islamic system of religious hierarchization, in particular the so-called Pact of 'Umar, seems highly questionable. ${ }^{95}$

\section{Carolingian knowledge about the Muslim treatment of non-Muslims}

It is certain, however, that the Carolingians were aware of the Muslim conquest of the Iberian Peninsula and of the fact that the population of the former Visigothic realm was now subject to a new ruling elite. It is highly probable that, in the period between the Muslim invasion of the Iberian Peninsula in 711 and the beginning of the Saxon campaigns in the 770s, the ruling elites of the Frankish realm had formed some kind of image of the living conditions under Muslim rule. To find out what the Carolingians perceived as the Muslim treatment of non-Muslims in al-Andalus, it is necessary to turn to Latin-Christian sources produced under Frankish rule.

The Carolingians first came into contact with the Muslims of al-Andalus when their quest of extending their influence to Aquitaine intersected with the earliest Muslim raids into southern Gaul. The ensuing relations have been treated extensively by 'Abd al-Raḥmān 'Alī al-Ḥajjì as well as Philippe Sénac, ${ }^{96}$ and are documented not only in largely contemporary Latin, but also

94 Mālik b. Anas (d. 179/795), Al-muwațțā' bi-riwāyatihi Yahyaa al-Laythī (d. 234/848), ed. Salīm bin 'Abd al-Hadālī as-Salafì, Book 17 (kitāb al-zakāt), hadīth 673 (45), 293: "wa-ḥaddathanì 'an Mālik annahu balaghahu anna 'Umar bin 'Abd al-'Azīz, kataba ilā 'ummālihi an yaḍ'ū al-jizya 'amman aslama min ahl al-jizya hịna yuslimūn: qāla Mālik maḍat al-sunna an lā jizya 'alā nisā’ ahl al-kitāb wa-lā 'alā șibyānihim wa-anna l-jizya lā tu’ khadh illā min al-rijāl alladhīna qad balaghū al-ḥulum wa-laysa 'alā ahl al-dhimma wa-lā alā l-Majūs fĩ nakhîlihim wa-lā kurūmihim walā zurūi ihim wa-lā mawāshīhim ṣadaqa li-anna l-ṣadaqa innamā wuḍiat 'alā l-muslimīn tațhīran lahum wa-raddan 'alā fuqarā ihim wa-waḍa'at al-jizya 'ahā ahl al-kitāb șaghāran lahum fa-hum mā kānu bi-baladihim alladhīna șālaḥu 'alayhi laysa 'alayhim shay’ siwā l-jizya fĩ shay' min amwālihim illā anna yattajirū fĩ bilād al-musliminn wa-yakhtalifū fihā fa-yu’khadh minhum al-'ushr fimā yadīrūna min al-tijārāt wa-dhālik annahum innamā wuḍi'at 'alayhim al-jizya wa-șālaḥū 'alayhā 'alā an yuqarrū bi-bilādihim wa-yuqātil 'anhum 'adūwuhum fa-man kharaja minhum min bilādihi ilā ghayrihā yatjar ilayhā fa-'alayhi al-ushr (...) wa-hādhā alladhỉ adraktu 'alayhi ahl al-'ilm bi-baladinā«; translation adapted from http://ahadith.co.uk/permalink-hadith-669 (retrieved on 17 May 2016).

95 A point already underscored by Nelson, Religion and Politics, 24.

96 El-Hajji, Andalusian Diplomatic Relations; El-Hajji, Political Relations of Andalusian Rebels, 56-70; Sénac, Musulmans et Sarrasins; Sénac, Carolingiens et al-Andalus. 
in later Arabic-Islamic sources. ${ }^{97}$ The extant sources suggest several possibilities by which the Carolingian ruling elite of the late eighth century could have been informed about the living conditions of non-Muslims under Muslim rule in al-Andalus and even North Africa.

\section{Pathways of transmission}

The earliest Muslim raids into Frankish territory took place in the $720 s .{ }^{98}$ An ambivalent figure in this context is Eudo, the dux of Aquitaine, who is credited with having defended the Frankish realm from Saracen attacks in some sources, accused of collaboration with the latter in other sources.Two Hispano-Latin chronicles claim that Eudo's troops routed the Muslims at Toulouse, killing their governor al-Samb (ruled c. 100-02/719-21). ${ }^{99}$ In the Liber pontificalis, Eudo even appears as the person responsible for defending the Frankish realm from the Saracen onslaught in 725-26. ${ }^{100}$ Sources produced in the Carolingian orbit, in turn, accuse Eudo of having incited either the same or a later Muslim incursion into the Frankish realm. ${ }^{101}$ Paul the Deacon points to tensions between Eudo and Charles Martel. In line with earlier sources claiming that Eudo was eventually forced to call Charles for help, he states that both joined forces against the Saracens around $732 .{ }^{102}$

Regardless of his exact loyalties, Eudo had the possibility of acquiring and transmitting information, not only about the Muslim conquerors of the Iberian Peninsula, but also about the Arab treatment of Berbers on the Iberian Peninsula and, possibly, in North Africa. According to the Hispano-Latin Chronicle of 754, he married one of his daughters to a Berber chief (unus ex Maurorum gente) called "Munnuz« to forestall Muslim attacks against the Frankish realm. Munnuz, in turn, seems to have collaborated with Eudo to achieve independence from Arab rule in a period preceding the great Berber revolt. Munnuz rebelled against the new Andalusian governor 'Abd al-Raḥmān b. 'Abd Allāh al-Ghāfiqi (ruled 112-14/730-32) in 731, but was captured and beheaded, whereas Eudo's daughter was received honourably by 'Abd al-Rahmān and then sent to the caliph in Damascus. ${ }^{103}$ It is unclear how this information relates to the report provided by the Gesta episcoporum Autissiodorensium which mention that Aimo, the ruler of Zaragoza, broke a marriage alliance involving Eudo's daughter Lampagia. ${ }^{104}$ All sources referring to Eudo agree, however, that he was, in some way or another, enmeshed in the complex frontier situation in the border zone between al-Andalus and the Frankish realm. ${ }^{105}$ Since Eudo is credited with having eventually collaborated with Charles Martel in all sources, we may surmise that the knowledge he acquired about circumstances under Muslim rule would have been transmitted to the leading Carolingian of his day.

97 König, Arabic-Islamic Views of the Latin West, 189-201.

98 Sénac, Carolingiens et al-Andalus, 11-17; König, Arabic-Islamic Views of the Latin West, 190-192.

99 Continuatio byzantia-arabica/Continuatio hispana, § 40/§ 86, ed. Mommsen, 358; Chronicon Moissiacense, a. 715, ed. Pertz, 290.

100 Liber pontificalis 91 (Gregorius II, sed. 715-731), § 182 (§ XI), ed. Duchesne, vol. 1, 401.

101 Chronicarum quae dicuntur Fredegarii scholastici continuationes, c. 13, ed. Krusch, 175; Annales Fuldenses, a. 725, ed. Pertz and Kurze, 2; Gesta abbatum Fontanellensium, ed. Loewenfeld, 9.29; Annales Mettenses priores, a. 732, ed. de Simson, 27.

102 Paulus Diaconus, Historia Langobardorum, 6.46, ed. Waitz, 233; Continuatio hispana, § 103-04, ed. Mommsen, 361; Chronicon Moissiacense, a. 732, ed. Pertz, 291.

103 Continuatio hispana, § 102, ed. Mommsen, 361; cf. Wolf, Conquerors and Chroniclers, 144, n. 154.

104 Gesta episcoporum Autissiodorensium, ed. Waitz, 394.

105 Sénac, Carolingiens et al-Andalus, 17-31. 
Eudo was not the only potential transmitter of information. Other members of local elites in Aquitaine also seem to have collaborated with the Muslims. Certain chronicles even claim that the region of Avignon fell to the Saracens in 737 »because of treason committed by the local ruling elites. ${ }^{106}$ Moreover, we should consider that Muslim forces soon took control of parts of southern Gaul, including the city of Narbonne and the region around Arles, thus establishing relations with the local population. ${ }^{107}$ An early counter-campaign conducted by Charles Martell seems to have been unsuccessful. ${ }^{108}$ The Muslims of Narbonne were expelled by his son Pippin who, after his victory around 752, was hampered in his quest of protecting Narbonne by the rebellious $d u x$ of Aquitaine, Waifar, around 761-762. ${ }^{109}$ Pippin, however, did not only engage in hostilities with Muslims, but also received Saracen envoys - one from the governor of Girona and Barcelona, ${ }^{110}$ another from Abbasid Baghdad, thus initiating LatinChristian diplomatic relations with the Islamic sphere. Since the Abbasid delegation wintered in the city of Metz, there must have been ample opportunities for exchange. ${ }^{111}$ Thus, even before Charlemagne assumed power or ventured into the so-called Spanish March, the Carolingians had access to various sources of information on living conditions under Muslim rule.

Charlemagne's involvement in northeastern Spain intensified this flow of information. It brought him into direct negotiations with various dissident representatives of Muslim authority on the Iberian Peninsula, i.e. when "Saracens « from the northern part of the Iberian Peninsula allegedly submitted to him in $777,{ }^{112}$ when Ibn al-A 'rābi and Ibn Yūsuf visited Charlemagne's court in the same year, ${ }^{113}$ allegedly presenting the king with the cities they governed ${ }^{114}$ and persuading him to intervene in Spain. ${ }^{115}$ Moving into the so-called Spanish March, Charlemagne and his entourage engaged with various Muslims, including hostages taken in Zaragoza. ${ }^{116}$ The ensuing period witnessed an intensification of contact with the northeastern parts of the Iberian Peninsula: as we will see shortly, the earliest settlement of Hispanic refugees in Carolingian territory took place in the 780s. Moreover, Charlemagne's campaign led to Carolingian interest in the so-called `Adoptionist heresy،. Felix of Urgel, of whom Alcuin claims that he has »never

106 Gesta abbatum Fontanellensium 10, ed. Loewenfeld, 32: per fraudem quorundam provintialium comitatum illum; Annales Mettenses priores 10, a. 737, ed. de Simson, 29; cf. Chronicarum qui dicuntur Fredegarii scholastici continuationes 20, ed. Krusch, 177 .

107 Chronicon Moissiacense, a. 715, ed. Pertz, 290.

108 Gesta abbatum Fontanellensium 10, ed. Loewenfeld, 32; Chronicarum qui dicuntur Fredegarii scholastici continuationes 20, ed. Krusch, 177; Paulus Diaconus, Historia Langobardorum, 6.54, ed. Bethmann and Waitz, 237.

109 Annales Mettenses priores, a. 752, ed. de Simson, 43; Chronicarum qui dicuntur Fredegarii scholastici continuationes 44, ed. Krusch, 188; Chronicon Moissiacense, a. 752 and 759, ed. Pertz (MGH SS 1), 294; cf. Sénac, Carolingiens et al-Andalus, 37-40.

110 Annales Mettenses priores, a. 752, ed. de Simson, 43, 13.

111 Chronicarum qui dicuntur Fredegarii scholastici continuationes, cap. 51, ed. Krusch, 191; cf. McCormick, Pippin III, 221-241.

112 Annales Mettenses posteriores, a. 777, ed. de Simson, 99.

113 Annales Mettenses priores, a. 777, ed. de Simson, 65; Annales regni Francorum, a. 777, ed. Pertz and Kurze, 48.

114 Annales qui dicuntur Einhardi, a. 777, ed. Pertz and Kurze, 49.

115 Annales qui dicuntur Einhardi, a. 778, ed. Pertz and Kurze, 51: ex persuasione praedicti Sarraceni; cf. Annales Mettenses priores, a. 778, ed. de Simson, 66, where the initiative resides with the Hispanic Christians.

116 Annales Mettenses posteriores, a. 778, ed. de Simson, 99; Annales qui dicuntur Einhardi, a. 778, ed. Pertz and Kurze, 51; Chronicon Moissiacense, a. 778, ed. Pertz, 296. 
seen a disputation of Felix with a Saracen, nor has it taken place in our presence «, ${ }^{117}$ was summoned to the presence of the king in $793 .{ }^{118}$ At the end of the eighth century, various embassies from Alfonso II of Asturias reached the Carolingian court. ${ }^{119}$

Even if we assume that some of this information recorded in Carolingian chronicles aspires to legitimize Charlemagne's Hispanic campaign and to enlarge the prestige of the king, it nonetheless provides ample evidence for the fact that various pathways of transmission provided Charlemagne with information about the political situation and the living conditions of Christians in Muslim al-Andalus.

\section{Carolingian sources on living conditions under Muslim rule}

Having established this, we may turn to the question how living conditions under Muslim rule were evaluated in Latin sources produced within the Frankish realm. Although Muslim rule is not depicted positively, it is not clearly associated with the Muslims' religion until the very late eighth century, if not the reign of Louis the Pious.

The Annales Mettenses priores depict Pippin's conquest of Narbonne in 752 as an act by which the king "liberated the Christians from service to the Saracens. ${ }^{120}$ The Chronicle of Moissac notes that the situation of Christians and Jews deteriorated extremely in the reign of the first Umayyad amìr, 'Abd al-Rahmān I. The latter is described as »the cruellest of all kings of the Saracens who were in Spain before him." He is depicted as having "oppressed the Christians and Jews of Spain by demanding so much tribute that they sold their sons, daughters and servants, the few remaining suffering from penury." One could interpret this passage as a clear acknowledgement of the early Umayyad establishment of a rigidly enforced dhimma-system. One should take note of the fact, however, that, according to the chronicler, 'Abd al-Rahmann was equally cruel to Saracens and Moors, killing many of them, including the former governor Yùsuf b. 'Abd al-Rahmañn al-Fihrī, the latter's sons as well as his own brother, thus leaving Spain in turmoil and depopulated to his son Hishām, the latter equally depraved. ${ }^{121}$ When Charlemagne set out on his campaign to the Iberian Peninsula, the Annales Mettenses posteriores tell us that he was "moved by the pleas and complaints of the Christians who were under the yoke of the Saracens in Spain «; ${ }^{122}$ the Annales Mettenses priores specify "the yoke of the evil Saracens $« .{ }^{123}$ With regards to these sources, it is very

117 Alcuinus, Epistolae 172, ed. Dümmler, 284: Disputationem itaque Felicis cum Sarraceno nec vidi nec apud nos inventa est.

118 Annales qui dicuntur Einhardi, a. 793, ed. Pertz and Kurze, 95; cf. Chronicon Moissiacense, a. 794, ed. Pertz, 300301.

119 Einhardus, Vita Karoli Magni 16, ed. Holder-Egger, 19.

120 Annales Mettenses priores, a. 752, ed. de Simson, 43: Christianos de servitio Sarracenorum liberavit.

121 Chronicon Moissiacense, a. 793, ed. Pertz, 300: His temporibus regnabat in Spania Exam, filius Abderraman Ibn-Mavia. Iste Ibin-Mavia debellavit Iusseph-Ibin-Abderraman et occidit eum et filios eius, regnavitque pro eo in Spania annis 33 menses 4. Hic crudelior omnibus regibus Sarracenorum fuit qui ante eum fuerunt in Spania, diversis cruciatibus interemit innumerabiles Sarracenos et Mauros, filium quoque patris sui, fratrem suum, truncatis manibus et pedibus igni cremare iussit. Christianos in Spania et Iudaeos in tantum tributa exigendo oppressit, ut filios suos et filias suas atque mancipia venderent, et pauci relicti penuria afficerentur; et per pressuram ipsius tota Spania conturbata et depopulata est. Mortuus est autem Ibin-Mavia, et regnavit Exam filius eius pro eo, fecitque malum sicut fecerat pater eius.

122 Annales Mettenses posteriores, a. 778, ed. de Simson, 99: motus precibus et querelis Christianorum, qui erant in Hispania sub iugo Sarracenorum.

123 Annales Mettenses priores, a. 778, ed. de Simson, 66: motus precibus, immo quaerelis Christianorum, qui erant in Hispania sub iugo sevissimorum Sarracenorum (...) exercitum in Hispaniam duxit. 
difficult to judge, if Charlemagne and his entourage really regarded the Muslims as so evil as to become involved in an additional campaign or if the chroniclers depicted the Saracens as evil in the hope of justifying Charlemagne's failed Spanish adventure. It is clear, in any case, that all sources treated so far oppose religiously undefined conquerors to Christian and Jewish subjects: the religious status of the former is not clear; the existence of a system of religious hierarchization suggests itself, but is not explicitly mentioned.

Charlemagne's entourage did not view the Muslims favourably. In a letter written around 786, Alcuin defines hypocrisy as a sSaracen trait. ${ }^{124}$ Around 790, Alcuin lauds the king's duces for having fought against the Saracens in Spain and bewails that the latter controlled great parts of Asia and Africa. ${ }^{125}$ Theodulf, proposed by Hen as Charlemagne's prime informer about the situation of non-Muslims under Muslim rule on the Iberian Peninsula, rarely mentions Arabs or Saracens in his works. A poem about insatiable greed and avarice features a list of oriental gifts, some of them defined as Arab. ${ }^{126}$ In other poems the ethnonym Arab is linked to negative attributes such as "sinister " (ater, torvus). ${ }^{127}$ A poem directed at Charlemagne calls on Córdoba to endow its treasures to someone who deserves it, and orders Arabs, compared to the Avars, to bow their necks at the feet of the king. ${ }^{128}$ The Capitulare de imaginibus in the Libri Carolini, generally attributed to Theodulf, ${ }^{129}$ claims that "Arab wolves have jeered by appearing as if they had clothed themselves in sheepskins and, having bypassed the truth, have accepted the lie (...).«, thus reproducing an extract from the acts of the second council of Nicaea (787). ${ }^{130} \mathrm{~A}$ farewell poem to Louis the Pious contains the wish that Moors and Arabs may give way to him. ${ }^{131}$ The general tone of Theodulf's references to Arabs, Saracens etc. implies that he was not sympathetic to Muslims, was aware that they followed

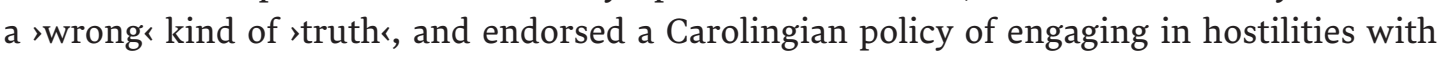
Muslim al-Andalus. Such an attitude would not have been held by someone who regarded the Muslim system of administrating multireligiosity as worth emulating. As Janet Nelson put it: »Theodulf, the refugee from Spain, makes an improbable jihadi.« ${ }^{132}$

124 Alcuinus, Epistolae 3, ed. Dümmler, 22: Nono capite, ut nullus ex ecclesiasticis cibum in secreto sumere audeat, nisi prae nimia infirmitate, quia hypocrisis et Saracenorum est.

125 Alcuinus, Epistolae 7, ed. Dümmler, 32: Etiam et eiusdem christianissimi regis duces et tribuni multam partem Hispaniae tulerunt a Saracenis, quasi trecenta milia in longum per maritima. Sed heu pro dolor, quod idem maledicti Saraceni, qui et Aggareni, tota dominantur Affrica, et Asia maiore maxima ex parte. De quorum egressione tue venerande prudentiae dudum, ut estimo, scripsi.

126 Theodulfus Aurelianensis, Carmina 7.11, ed. Dümmler, 461: Atque Eudaemonicus munera portet Arabs. // Si veniat Bagatat Agarenis rebus onusta, / Urbs et Achaemeniis quae fuit alta locis. // Tigris et Euphrates quod habet, Iordanis et ipse, / Atque Palaestinus fert benedictus ager.

127 Theodulfus Aurelianensis, Carmina 28., v. 173-176, 211-212, ed. Dümmler, 498-499: Alter ait: Mihi sunt vario fucata colore / Pallia, quae misit, ut puto, torvus Arabs. Theodulfus Aurelianensis, Carmina 29, v. 15, ed. Dümmler, 518: Aut fucata nitens, quas habet ater Arabs.

128 Theodulfus Aurelianensis, Carmina 25, v. 41, ed. Dümmler, 484: Adveniunt gentes Christo servire paratae, / Quas dextra ad Christum sollicitante vocas. // Pone venit textis ad Christum crinibus Hunnus, / Estque humilis fidei, qui fuit ante ferox. // Huic societur Arabs, populus crinitus uterque est, / Hic textus crines, ille solutus eat. // Cordoba, prolixo collectas tempore gazas / Mitte celer regi, quem decet omne decens. // Ut veniunt Abares, Arabes Nomadesque venite, / Regis et ante pedes flectite colla, genu. // Nec minus hi, quam vos, saevique trucesque fuere, / Sed hos qui domuit, vos domiturus erit.

129 Cf. Freemann, Theodulf of Orléans.

130 Opus Caroli regis contra synodum (Libri Carolini) 4.22, ed. Freemann and Meyvaert, 542: et lupi Arabici exsistentes pellem ovium subsannaverunt indueri et veritatem praetereuntes mendacium amplexi sunt (...).

131 Theodulfus Aurelianensis, Carmina 39, v. 9, ed. Dümmler, 531: Maurus tibi cedat Arabsque.

132 Nelson, Religion and Politics, 24. 
Sources providing further insight into the Carolingian perception of the Muslim treatment of non-Muslims stem from the period when the issue of subjecting the Saxons was essentially solved from a Carolingian perspective. Apart from a diploma issued in 795 for a Iohannes from the pagus of Barcelona, granting him possessions near Narbonne for having fought against »heretics or Saracen infidels" (ereticos sive Saracenos infideles), ${ }^{133}$ Charlemagne's Praeceptum pro Hispanis dating from 812 represents the first royal document that explicitly deals with Hispanic refugees in the Frankish realm. ${ }^{134}$ It speaks of "our Spaniards who have come from Spain relying on us «, ${ }^{135}$ but refrains from depicting their former living conditions under Muslim rule. The aim of the document, directed at the local comites of the so-called Spanish March responsible for these refugees, ${ }^{136}$ is to protect the latter from the comites' oppression and fiscal exploitation. ${ }^{137}$ These Spaniards had apparently arrived in the Frankish realm around thirty years before the document was issued, ${ }^{138}$ i.e. in the late 770 s or early 780 s. We must thus conclude that these Hispani were not refugees from the Muslim invasion of the Iberian Peninsula which had affected the latter's northern region already in the second decade of the eighth century. Rather, their flight seems to have been related to regional turbulences in the late 770 , i.e. the rebellions of various local Muslim governors against Umayyad Córdoba that allowed Charlemagne to intervene in 777-78. Not all Hispani seem to have been Latin Christians: among the persons who had complained to the king, thus eliciting his written reaction, we find two men carrying the name "Zoleiman « (Ar. Sulaymān) and "Zatamiliteis « (Ar. Sa dün?). ${ }^{139}$ Consequently, we must thus ask ourselves if these refugees were fleeing Muslim domination, as not only Hen, but also Philippe Depreux, Xavier Gillard and Philippe Sénac purport, or rather an unstable political situation and constant military activity in a region claimed simultaneously by the Umayyads of Córdoba, local potentates and Carolingian elites. ${ }^{140}$ This also applies to the more prominent Hispanic refugees such as Theodulf of Orléans and Agobard of Lyon, both of whom are assumed to have settled in the Frankish realm

133 Diploma 179, ed. Mühlbacher, 241-242. Cf. Gillard and Sénac, À propos de quelques Hispani, 165-166, 167.

134 See the deliberations of Depreux, Préceptes pour les Hispani, 23-24, concerning the question, if Charlemagne had already issued decrees immediately after his Spanish campaign, a hypothesis formulated by several Spanish and Catalan scholars.

135 Praeceptum pro Hispanis (2 April 812), ed. Boretius, § 76, 169: Ispanos nostros, qui ad nostram fiduciam de Ispania venientes.

136 Praeceptum pro Hispanis (2 April 812), ed. Boretius, $§ 76,169$ : quia isti Ispani de vestra ministeria.

137 Praeceptum pro Hispanis (2 April 812), ed. Boretius, $§ 76,169$ : quod multas oppressiones sustineant de parte vestra et iuniorum vestrorum, et dixerunt, quod aliqui pagenses fiscum nostrum sibi alter alterius testificant ad eorum proprietatem et eos exinde expellant contra iusticiam et tollant nostram vestituram, quam per triginta annos seu amplius vestiti fuimus et ipsi per nostrum donitum de eremo per nostram datam licentiam retraxerunt. Dicunt etiam, quod aliquas villas, quas ipsi laboraverant, laboratas [ab] illis eis abstractas habeatis et beboranias illis superponatis et saiones, qui per fortia super eos exactant. (...) Propterea has litteras fieri precepimus atque demandamus, ut neque vos neque iuniores vestri memoratos Ispanos nostros (...) nullum censum superponere presumatis neque ad proprium facere permittatis, quoadusque illi fideles nobis aut filiis nostris fuerunt, quod per triginta annos habuerunt per aprisionem, quiti possideant eilli et posteritas eorum et vos conservare debeatis.

138 Praeceptum pro Hispanis (2 April 812), ed. Boretius, $§ 76,169$ : nostram vestituram, quam per triginta annos seu amplius vestiti fuimus (...) quod per triginta annos habuerunt per aprisionem; cf. Gillard and Sénac, À propos de quelques Hispani, 166.

139 Gillard and Sénac, À propos de quelques Hispani, 168, on the possible identity of these men.

140 Gillard and Sénac, À propos de quelques Hispani, 166, emphasize »que c'est le contexte politique et militaire qui détermina le rythme de la migration«, but assume - in spite of the lack of evidence - that these refugees were made up of people »refusant la domination musulmane«. In the same vein, Depreux, Préceptes pour les Hispani, 23, claims: "Ces Hispani avaient fui la domination de l'émirat d'al-Andalus pour se réfugier sous la tutelle, franque, c'est-à-dire sous une tutelle chrétienne.« 
in about the same period, i.e. the 780s, as well as Prudentius of Troyes, assumed to have left the Iberian Peninsula later. Yet concrete and reliable evidence about the time and motivation of migration is lacking in all three cases. ${ }^{141}$

The Hispani are mentioned again in the Constitutio de Hispanis issued by Louis the Pious in $815 .{ }^{142}$ Again, the document was issued because the local authorities had failed to respect the rights of Hispanic refugees already spelt out in Charlemagne's Praeceptum of 812. As opposed to the latter document, Louis' Constitutio clearly spells out the refugees' motivation for seeking refuge in the Frankish realm.

Since we believe«, Louis wrote, "that it cannot have escaped your notice how, because of the unjust oppression and the cruel yoke which the people of the Saracens, most inimical to Christianity (inimicissima Christianitati), has imposed upon their necks, a number of men have fled to us from parts of Spain after leaving behind their own dwellings and possessions which belonged to them from hereditary right, and have settled in Septimania and in that part of Spain which has been left deserted by our margraves, and - eluding the power of the Saracens - have subjected themselves to our dominion by their free and obvious will, we want to make known to all of you that we have decreed that these men, received under our protection and defence, shall maintain their liberty.»

In this context, Louis not only mentions Hispani, "who reside in these places at present«, but also Hispani who, "until this time will have sought refuge under our custody from the power of their enemies. ${ }^{143}$

As already noted by Philippe Depreux, the tone of this document is much harsher and clearly defines the Saracens as enemies of Christianity. ${ }^{144}$ This accords well with other sources produced under the rule of Louis the Pious, such as Ermoldus Nigellus' poem of praise (written c. 823-30): it does not only feature the story of the Frankish soldier Datus who witnesses how his mother was killed by a cruel Saracen, ${ }^{145}$ but also claims that Louis the Pious legitimized military action against the Muslims by pointing to their refusal to accept Christianity:

If this people venerated God and pleased Christ, / and were bewetted with the unction of holy baptism, / then we would be obliged to conclude peace, and to hold this peace, / so that it could be joined, through God, with religion. / But it remains execrable and spurns our / Salvation, and follows the orders of the demon. ${ }^{146}$

141 Cf. Brunhölzl, Geschichte der lateinischen Literatur, vol. 1, 288 (Theodulf), 415 (Agobard); Girgensohn, Prudentius und die Bertinianischen Annalen, 1.

142 Constitutio de Hispanis prima, ed. Boretius, § 132, 261-263.

143 Constitutio de Hispanis prima, ed. Boretius, § 132, 261: Sicut nullius vestrum notitiam effugisse putamus, qualiter aliqui homines propter iniquam oppressionem et crudelissimum iugum, quod eorum cervicibus inimicissima Christianitati gens Sarracenorum imposuit, relictis propriis habitationibus et facultatibus quae ad eos hereditario iure pertinebant de partibus Hispaniae ad nos confugerunt, et in Septimania atque in ea portione Hispaniae quae a nostris marchionibus in solitudinem redacta fuit sese ad habitandum contulerunt, et a Sarracenorum potestate se subtrahentes nostro dominio libera et prompta voluntate se subdiderunt, ita ad omnium vestrum notitiam pervenire volumus, quod eosdem homines sub protectione et defensione nostra receptos in libertate conservare decrevimus. (...) Sed liceat tam istis Hispanis, qui praesenti tempore in praedictis locis resident, quam his qui adhuc ad nostram fidem de iniquorum potestate fugiendo confluxerint et in desertis atque in incultis locis per nostram vel comitis nostri licentiam consedentes aedificia fecerint et agros incoluerint, iuxta supradictum modum sub nostra defensione atque protectione in libertate residere (...); trans. by the author.

144 Depreux, Préceptes pour les Hispani, 23. On the question if Louis thus used a concept of »Christendom« opposed to a "Saracen«, i.e. Islamic sphere, see Geelhaar, Christianitas, 332, n. 84.

145 Ermoldus Nigellus, Carmen in honorem Hludowici, 1, v. 207-266, ed. Dümmler, 11-13.

146 Ermoldus Nigellus, Carmen in honorem Hludowici, 1, v. 281, ed. Dümmler, 13: Si gens ita deum coleret, Christoque placeret, / Baptismique foret unguine tincta sacri, / Pax firmanda esset nobis, pax atque tenenda, / Coniugi ut possit relligione deo. / Nunc vero execranda manet, nostramque salutem / Respuit, et sequitur daemonis imperia. / Idcirco hanc nobis pietas miserata tonantis / Servitii famulam reddere namque valet; ; trans. Kedar, Crusade and Mission, p. 7 
Notwithstanding, documents attributed to Louis the Pious do not necessarily bespeak a sweeping condemnation of the Muslim faith on the part of the king. The Constitutio de Hispanis secunda, issued 10 February 816, also mentions Hispani, "who have eluded the power of the Saracens and have sought refuge under our or our father's custody «, ${ }^{147}$ but refrains from the polemics characteristic of the document issued one year earlier. Even more interesting is a letter written by Louis around 830 to the entire people of Mérida (cuncto populo Emeritano). It is unclear, if this letter, referring to Jesus Christ in the Invocatio, was really addressed to all religious groups which, in the 820 s, must have populated the city of Mérida. In the letter, the king refers to an unjust form of tribute exacted from the city's populace by the ruling amīr 'Abd al-Raḥmān II (ruled 206-38/822-52) and introduced by his father al-Ḥakam I (ruled 180-206/796-822):

We have heard of your tribulation and the multifaceted fears which you have endured because of the cruelty of King Abdiraman who, because of his insatiable greed for your possessions, which he has tried to take away from you, has often oppressed you violently. As we have learned, his father Abolaz had already done the same thing, who forced you to pay an unjustly imposed tax (censum) to him, of which you were not the debtors, thus transforming you from friends into foes and from obedient subjects of his to disobeying rebels because he wanted to deprive you of your liberty as well as burden and humiliate you with unjust taxes and tributes. ${ }^{148}$

Louis the Pious, involved in the affairs of Aquitaine and northeastern Spain from an early age onwards, was probably better informed about affairs of the Iberian Peninsula than his late father. The documents cited above suggest, moreover, that he may have been ideologically more averse to the Saracens whom he seems to have regarded as enemies of the Christian faith. The tribute exacted by these Saracens and explicitly mentioned by Louis is not defined, however, in religious terms, but simply as a form of oppression. According to his letter to the populace of Mérida, Louis associated this oppression, not with Islam, but with a specific period and individual rulers who destroyed pre-existing friendly relations existing up to the early reign of al-Ḥakam I by exacting unjust and humiliating forms of tribute. Thus, as late as 830, there is still no indication that the ruler of the Frankish realm had a clear conception of Islam, nor of a specifically Islamic system of dealing with non-Muslims.

The definition of the Saracens as enemies of Christianity, first formulated by Louis the Pious in 815, was taken up again by Charles the Bald in his Praeceptum pro Hispanis of 844, explicitly modeled on the earlier documents of Charlemagne and Louis the Pious. ${ }^{149}$ The Christian dimension of receiving Spanish refugees is much stronger, however, as already

147 Constitutio Hludowici de Hispanis secunda (10 Feb. 816), ed. Boretius, no. 133, 263: Hispani, qui de potestate Sarracenorum se subtraxerunt et ad nostram seu genitoris nostri fidem se contulerunt (...); trans. by the author.

148 Einhartus, Epistolae 12, ed. Hampe, 115-116: Audivimus tribulationem vestram et multimodas angustias, quas patimini per crudelitatem regis Abdiraman, qui vos per nimiam cupiditatem rerum vestrarum, quas vobis auferre conatus est, sepissime violenter oppressit. Sicut et patrem eius Abolaz fecisse conperimus, qui iniustis superpositionibus censum, cuius debitores non eratis, sibi vos solvere cogebat et propter hoc de amicis inimicos et de obedientibus sibi contrarios atque inobedientes effecerat; quia et libertatem vobis tollere et iniustis censibus ac tributis vos honerare atque humiliare molitus est; trans. by the author.

149 Praeceptum pro Hispanis (11 June 844), ed. Boretius, § 256, 259: crudelissimum iugum inimicissimae christiani nominis gentis Sarracenorum evitantes ... ab eorumdem Sarracenorum potestate se subtrahentes", 26o: "qui adhuc ad nostram fidem de iniquorum potestate fugiendu confluxerint. 
noted by Philippe Depreux: Charles the Bald emphasizes the religious dimension of giving assistance to fellow Christians, ${ }^{150}$ demands that the Hispani should be received as belonging to the "unity of the faith «, ${ }^{151}$ and decrees that the Hispani should be protected »by all faithful of the holy church of God«. ${ }^{152}$

In sum, it is possible to validate Hen's hypothesis that the Carolingians were much better informed about the situation of Christians in al-Andalus than can usually be gleaned from general accounts of the Carolingian era that do not focus, as does Philippe Sénac, on relations with Muslim Spain, or from general studies of Latin-Christian images of Islam that rarely provide a detailed description of Carolingian perceptions of Islam. ${ }^{153}$ It may be added that the few existing studies on the Carolingian perception of Islam highlight that the latter cannot be reduced to negative stereotypes. ${ }^{154}$ Corroborating these studies, analysis of the aforementioned sources procured the following results: Carolingian elites before, in and after the time of Charlemagne were very aware of the Muslim presence on and beyond the Iberian Peninsula, generally deemed hostile, but dealt with pragmatically if necessary. Carolingians, at the latest from Charlemagne onwards, were aware of the fact that the so-called Saracens were not Christians, but either heretics or infidels. ${ }^{155}$ However, an explicit definition of the latter as anti-Christian non-Christians only appears in the reign of Louis the Pious, that is, long after the Carolingian takeover of Saxony. ${ }^{156}$ Although Carolingian sources frequently mention tribute exacted from non-Muslims by Muslim authorities and, in sources post-815, even link the oppressive exercise of Saracen power and authority, including the exaction of tribute, to the Saracens' anti-Christian attitude, the extant texts do not betray a Carolingian awareness of a religiously justified Islamic system of religious hierarchization and taxation.

It is very difficult to form a judgement on the question of whether Charlemagne and his entourage regarded the Saracens as a deviant religious group subjecting and oppressing Christians and Jews by exacting tribute from them for religious reasons, or whether they merely regarded the Saracens as just another variant of non-Christianized foreign conquerors who, not being part of the political-ecclesiastical system of the Frankish realm, were not entitled to subject (Latin) Christians. Both the Chronicle of Moissac and Louis the Pious' letter to the people of Mérida suggest a Carolingian awareness of fluctuations in the Saracen treatment of subjected Christians and Jews. The fact that succeeding Umayyad rulers are evaluated differently implies that the Carolingian observers did not regard Muslim al-Andalus as a society functioning according to a uniform legal system, but rather as a society in which the situation of the subjected Christian population largely depended on the indi-

150 Praeceptum pro Hispanis (11 June 844), ed. Boretius, § 256, 259: quatenus et nostra regalis conservatio constructa atque innovatio in eorum bene gestis operibus exaltationi ecclesiae pretioso Christi sanguine redemptae et ministret augmentum et animabus eorum ac nostrae proficiat semper in emolumentum.

151 Praeceptum pro Hispanis (11 June 844), ed. Boretius, § 256, 259: sicut in unitate fidei.

152 Praeceptum pro Hispanis (11 June 844), ed. Boretius, § 256, 260: ab omnibus fidelibus sanctae Dei ecclesiae; cf. Depreux, Préceptes pour les Hispani, 23.

153 Cf. Daniel, Islam and the West; Southern, Western Views of Islam; Sénac, L'Occident face à l'Islam; Tolan, Saracens.

154 Mohr, Wissen über den Anderen, 68-75, 251-260, 294-298; Goetz, Sarazenen als Fremde, 39-66; Goetz, Wahrnehmung anderer Religionen, vol. 1, 233-410; Bade, Vorstellungen vom Islam und den Sarazenen, 89-120; Bade, Christlich-abendländische Wahrnehmung vom Islam, 83-119.

155 Diploma 179, ed. Mühlbacher, 241-42: ereticos sive Saracenos infideles.

156 Also see Kedar, Crusade and Mission, 9-13.

medieval worlds $\bullet$ No. $3 \cdot 2016 \cdot 3-40$ 
vidual non-Christian ruler. This accords with the fact that, in the Frankish realm, the earliest Latin sources describing concrete features of Muslim religion and society date from the tenth century. ${ }^{157}$

In spite of numerous military confrontations, the taking of captives and hostages, diplomatic exchange and other forms of communication and information transfer, early Carolingian images of Muslim society still seem to have been rather vague. Carolingian sources do not suggest that Charlemagne and his entourage clearly understood the functioning of the Islamic society of al-Andalus. This raises the question how they could have adopted a religiously defined hierarchized fiscal system from a society they only dimly understood. Since it is equally impossible to claim that the Carolingian elite around Charlemagne idealized or admired the so-called Saracens, we must ask ourselves why the Carolingians should have wanted to adopt the latter's religiously defined hierarchized fiscal system. If one really insisted on a migration of ideas from al-Andalus to the Carolingian court under the circumstances sketched out above, then this transcultural inspiration would would have had to have taken place unconsciously.

\section{The Capitulatio de partibus Saxoniae: Islamic or Christian influences?}

Hen's entire argument that this migration of ideas took place, hinges on specific passages of the Capitulatio de partibus Saxoniae which he defines as IIslamicr. According to Hen, the

decree has no precedent in the history of the Christian mission, and it seems to be more than a faint echo of the Islamic concept of jihad. I would like to suggest that it was indeed the notion of jihad, with which, no doubt, Theodulf was familiar, that stood behind the formulation of the Capitulatio's forced conversion policy. ${ }^{158}$

Closer analysis reveals, however, that the Capitulatio de partibus Saxoniae does not reflect a clear-cut Islamic system of dealing with infidels. Even if we assumed an Islamic influence, then the Capitulatio would contain a very particular mixture of IIslamic principles of treating non-Muslims.

The Capitulatio includes the threat of capital punishment for those refusing to be baptized, a ruling Hen leads back to the sIslamic principler of offering the choice between death or conversion to non-monotheists. ${ }^{159}$ Its primary source is Qur'ān 9:5, that orders its readers to aggress and kill those who associate something with God (al-mushrikunn), generally defined as polytheists, unless they repent, pray and pay the Muslim alms tax (zakāt). This call to forced conversion is attenuated to a certain degree, in that it (1) forms part of the only Qurannic surra not introduced by the basmallah, i. e. the invocation "in the name of God, the most gracious, the merciful«; (2) is clearly linked to the historical context of the early Muslims' conflict with the Meccans (9:1); (3) is surrounded by verses which require believers to respect treaty obligations with polytheists who have kept their pledges (9:4); and grants asylum and a safe-conduct to polytheists who seek refuge with the Muslims without forcing them to convert (9:6). In consequence, the inner-Muslim theological and juridical debate

157 Iohannis abbas s. Arnulf, Vita Iohannis abbatis Gorziensis,c. 119-123, ed. Pertz, 371-372, describes Muslim social customs in al-Andalus encountered by the Ottonian envoy John of Gorze in Córdoba. Rodulfus Glaber, Historiarum libri quinque 1.9, ed./trans. France, 20-22, describes the abduction of Maiolus, abbot of Cluny, and comments on the Saracens' acknowledgement of biblical prophets in this context.

158 Hen, Charlemagne's Jihad, 47.

159 Capitulatio de partibus Saxoniae 8, ed. Boretius, 69; cf. Hen, Charlemagne’s Jihad, 47. 
about these verses cannot be reduced to one single opinion on the correct Muslim conduct vis-à-vis non-monotheist non-Muslims. ${ }^{160}$ In the case of the Berbers, these Islamic principles seem to have been implemented by either demanding tribute from monotheist and nonmonotheist Berbers or by forcing them to become part of the Muslim army. The ruling of the Capitulatio is much more precise and leaves no interpretative options. ${ }^{161}$

The Capitulatio also obliges the Saxons to pay the tithe, a religious tax Hen wrongly equates with the jizya, i.e. the Muslim poll tax requisitioned from adherents to non-Muslim monotheistic speople of the book, instead of regarding it as the equivalent to the zakät, i.e. the (alms) tax required to be paid by (newly converted) Muslims ${ }^{162}$ In the Frankish realm of the eighth century, the tithe was not yet universally established. However, it had already been declared obligatory by several ecclesiastical authorities in and outside the Frankish realm in pre-Islamic times. ${ }^{163}$ To impose this tax, there was no need to draw on external inspiration, the more so as Alcuin's argument against the imposition of the tithe on the Saxons does not question its existence as such, but only its imposition on the newly converted. ${ }^{164}$

Hen believes that the Frankish legislator's satisfaction with seeing that the churches of Saxony receive greater honour than the temples of idols can be traced back to Islamic principles of prohibiting the construction and repair of synagogues and churches as well as of ensuring the greater height, higher visibility and prestige of Muslim edifices in hierarchized pluri-religious societies under Muslim rule. ${ }^{165}$ Apart from the Christianized Saxons who collaborated with the Franks, the religious landscape in Saxony at the end of the eighth century was dominantly non-monotheist. Had the Carolingian elite around Charlemagne looked for a system of how to deal with pagans, why did they deem it necessary to adapt Islamic rules for dealing with non-Muslim monotheist places of worship to pagan Saxon stemples - if sites such as the Irminsul, destroyed by the Frankish conquerors at the very beginning of the Saxon Wars, can be regarded as stemplesı? The discrepancy between the multi-religious urban environment that gave rise to Muslim legal norms and the situation in Saxony makes a "migration of ideas" seem implausible.

Finally, Hen interprets the Capitulatio's granting of church asylum as an inversion of a Muslim prohibition to give shelter to Muslim enemies in churches. ${ }^{166}$ Why would a Muslim precautionary measure ensuring that subjected populations did not use Christian places of worship to give shelter to potential enemies inspire the establishment of the institution of church asylum in Saxony, especially considering that the issue of church asylum is already

160 Cf. Crone, Thought, 370-372.

161 Capitulatio de partibus Saxoniae 8, ed. Boretius, 69: Si quis deinceps in gente Saxonorum inter eos latens non baptizatus se abscondere voluerit et ad baptismum venire contempserit paganusque permanere voluerit, morte moriatur; $\mathrm{cf}$. Hen, Charlemagne's Jihad, 47.

162 Capitulatio de partibus Saxoniae 17, ed. Boretius, 69; cf. Hen, Charlemagne's Jihad, 48.

163 Puza, Zehnt, 499-500; Toneatto, Dîme et construction, 65-86; Devroey, Introduction de la dîme obligatoire, 87106.

164 Alcuin, Epistolae 110, ed. Dümmler, 158: Scimus, quia decimatio substantiae nostrae valde bona est: sed melius est illam amittere quam fidem perdere. Nos vero, in fide catholica nati nutriti et edocti, vix consentimus substantiam nostram pleniter decimare; quanto magis tenera fides et infantilis animus et avara mens illarum largitati non consentit.

165 Capitulatio de partibus Saxoniae 1, ed. Boretius, 68: Hoc placuit omnibus, ut ecclesiae Christi, que modo construuntur in Saxonia et Deo sacratae sunt, non minorem habeant honorem sed maiorem et excellentiorem quam vana habuissent idolorum; cf. Hen, Charlemagne's Jihad, 48

166 Capitulatio de partibus Saxoniae, c. 2, ed. Boretius, 68; cf. Hen, Charlemagne’s Jihad, 49. 
discussed in detail in pre-Islamic sources such as the Theodosian Code $?^{167}$ In the same context, Hen interprets the phrase "concedatur ei vita et omnia membra" as referring to the so-called hadd-punishments of Islamic law, that stipulate death or mutilation in certain cases, ${ }^{168}$ without considering that both capital punishment and mutilation are integral features of Roman and post-Roman law. ${ }^{169}$

If we believed that Theodulf and Charlemagne were inspired by a Muslim system of legal thought, especially with regards to the position of non-Muslim religious groups within Muslim dominated societies, we would have to concede that they took an enormous amount of creative liberty when adapting this allegedly Islamic system to circumstances in Saxony. They would have reinterpreted, strongly modified and creatively mixed principles of dealing with pagans (forced conversion), non-Muslim monotheists (poll tax, building and repairing of churches and synagogues, church asylum) as well as with Muslims and non-Muslims alike (hadd-punishments). What Hen classifies as a the product of a "migration of ideas " would thus amount to a garbled mixture of legal principles, which again could not be assigned to a clear-cut Islamic system of dealing with other religions.

All in all, we may ask ourselves, why the Franks, assiduous compilers of Roman and vernacular legal traditions, should have needed the inspiration of Islamic norms and laws. Many of the rulings formulated in the Capitulatio de partibus Saxoniae could be explained as essential features of legislative action by right of conquest: many of the rulings of the Capitulatio serve to assure the conquerors' control of the newly acquired territory, while serving the enforcement of Christianity. According to Janet Nelson,

Charlemagne needed no external inspiration to legitimise war, whether against Saxons, Slavs, Avars or anyone else. The Christian Church had already provided such legitimisation long since, couching it, naturally, in terms of defence of the Church. It hadn't taken the young Charlemagne long to appreciate the political and economic benefits of religiously-sanctioned plundering. ${ }^{170}$

The argument that Charlemagne moved in a Christianized sphere that provided ample justification for the forced conversion of Saxony is seconded by various scholars who point, not only to Roman legal traditions, ${ }^{171}$ but also to contemporary eschatological interpretations of Christianity, ${ }^{172}$ as well as to the contemporary belief that Charlemagne's use of violence was justified from a Christian point of view. As Rachel Stone has recently stressed, eighth-century texts "repeatedly justify or take for granted aggressive warfare against both Christian and non-Christian opponents". In this context she points to the De conversione Saxonum carmen, dated 777, that depicts a Carolingian king who, based on "the strength of virtues, through javelins smeared with gore«, "dragged the forest-worshipping legions into the kingdom of heaven. «173

167 Codex Theodosianus 9. 45, ed. Mommsen.

168 Capitulatio de partibus Saxoniae, c. 2, ed. Boretius, 68; cf. Hen, Charlemagne’s Jihad, 49. On hadd-punishments see Carra de Vaux et al., Hadd, 20-22.

169 Geary, Judicial Violence and Torture, 81-82; cf. Körntgen, Heidenkrieg und Bistumsgründung, $283-287$.

170 Nelson, Religion and Politics, 23.

171 Cf. Körntgen, Heidenkrieg und Bistumsgründung, 282-287.

172 Ehlers, Jihad oder Parusieverzögerung 151-173.

173 De conversione Saxonum carmen, v. 45-47, ed. Dümmler, 381: Per vim virtutum, per spicula lita cruore / ... / Traxit silvicolas ad caeli regna phalanges, trans. Stone, Morality and Masculinity, 73. 
Considering the Latin-Christian tradition of justifying the use of force to eradicate non-Christian cults and to impose a Christian system of beliefs, cult and administration, ${ }^{174}$ the idea that Charlemagne may have been inspired by an Islamic system of religious hierarchization and $j i h \bar{a} d$, seems very far-fetched. A few well-known examples will suffice: Emperor Theodosius I (d. 395) is credited repeatedly with having instigated the destruction of >pagan< cult sites. ${ }^{175}$ In 408, Augustine argued in a letter to Vincentinus that it did not matter if someone was forced to do something, but if he was being forced to do something good or bad. ${ }^{176}$ In the same year, the Emperor Honorius ordered the destruction of all pagan altars as well as the confiscation of all temples under his dominion. ${ }^{177}$ Various Merovingian saints are credited with violence against pagan cult sites, ${ }^{178}$ while individual Merovingian, Visigothic and Lombard kings are credited with the forced conversion of Jews. ${ }^{179}$ As argued at the beginning of this article, these instances of linking coercion and conversion were intra-societal phenomena. We should not forget, however, that the idea of taking up arms against a neighbour not considered as adhering to the strue faith, in this case sheretic Visigoths, was already ascribed to one of Charlemagne's predecessors, i.e. the Merovingian King Clovis, by Gregory of Tours. ${ }^{180}$

\section{Conclusions}

The previous deliberations have shown that it is rather difficult to invalidate the most prevalent explanatory models that try to make sense of Charlemagne's forced conversion of the Saxons. There certainly exist enough arguments to prove that the Carolingian combination of conquest and forced conversion was the result of a particular historical constellation in which several factors contributed to the military escalation of relations between Franks and Saxons. Given the prominent role of (missionary) Christianity in Carolingian administration and its political legitimization of Carolingian rule, it can probably be regarded as inevitable that Christianity and the church would have become involved - in one way or the other - in the expansion of the Frankish realm. Given the previous history of Christian violence against non-Christian or deviant Christian groups as well as the history of justifying corresponding activities, the decision to spread Christianity by force can thus be regarded as a spotential option< in the progressing history of Christianization that would have been chosen sooner or later by the one or the other Christian warlords seeking to justify conquest and to make use of ecclesiastical administration to establish control over newly acquired territory, doing all this while maybe even acting in

174 Cf. Maier, Compelle intrare, 55-69.

175 Ambrosius, De obitu Theodosii oratio 4, ed. Faller, 373: Theodosius, qui - supplantavit perfidiam tyrranorum, qui abscondit simulacra gentium; omnes enim cultus idolorum fides eius abscondit, omnes eorum ceremonias obliteravit; ibid., 38, 391: qui sacrilegos removit errores, clausit templa, simulacra destruxit.

176 Augustine, Epistola 93 ad Vincentinum donatistam, ed. Goldbacher, 338, 349-350.

177 Codex Theodosianus 16.10, 19 (Nov. 407/o8), ed. Mommsen and Mayer: Templorum detrahantur annonae et rem annonariam iuvent expensis devotissimorum militum profuturae. (..) Aedificia ipsa templorum, quae in civitatibus vel oppidis vel extra oppida sunt, ad usum publicum vindicentur, arae locis omnibus destruantur omniaque templa in possessionibus nostris ad usus adcommodos transferantur (..).

178 König, Christliche >Helden< und Gewalt, 487-489.

179 Isidorus Hispalensis, Historia Gothorum Wandalorum Sueborum 6o, ed. Mommsen, 291; Chronicae quae dicuntur Fredegarii scholastici continuationes 4.65, ed. Krusch, 153; Carmen de sinodo Ticinensi, v. 3-10, ed. Bethmann and Waitz, 190.

180 Gregorius Turonensis, Libri historiarum decem, 2.37, ed. Krusch and Levison, 85. 
'good faithr. After all, Christianity was the symbolic language of the day, a symbolic language that permeated, or at least tried to permeate, all sectors of society, including the military.

Against this backdrop, the question of responsibility seems rather secondary: early medieval warrior elites would have engaged in conquest in any case, regardless of the presence of a new monotheistic belief system. Forces of conquest do not need monotheism to become active. This observation relativizes the hypotheses of Assmann and Buc to a certain degree: monotheistic religions cannot be held responsible for an increase of violence in the history of humankind. They certainly provided new and original forms of justifying violence, oppression and subjection. All in all, however, they just became part of the all too human game of exercising power over others in innumerable variants: before the forceful emergence of monotheistic ideas in early Antiquity, e. g. in the pre-Israelite Middle East, and outside their sphere of influence, e.g. the Roman-Celtic sphere or China, humans have also conquered, subjected and exerted violence in many ways.

Such a relativist stance seems unsatisfying, however. Charlemagne's forced conversion of the Saxons is certainly interesting from the perspective of a historian trying to understand the manifestations and to trace the development of a specific variant of monotheistic ideas. Regarded from an evolutionary point of view, it is interesting to see how a complex set of ideas (the teachings of Jesus and their Pauline interpretation) became an integral and directing part of several social bodies (early Christian groups), expanding and infiltrating a larger sociopolitical and economic system (the Roman Empire) and eventually moving beyond this embryonic body social by taking on the variant forms of missionary and even conquering Christianity. In this context, it is noteworthy that both the Carolingian conquest of Saxony and the Muslim invasion of the Iberian Peninsula led to the emergence of flourishing societies which, on the whole, professed the faith imposed on them while becoming loci of extremely high cultural activity and productivity. Rather than justifying or even encouraging the combination of violence and religious coercion, this observation should lead us to accept that radical, violent changes in a political and religious system are not only destructive, but create new means of cultural expression, among other things by connecting hitherto peripheral regions to new centres of cultural productivity.

To those empathizing with the Christian ideal of improving mankind, Charlemagne's forced conversion of the Saxons may seem shocking and in need of explanation: it seems to fall out of line with a process of Christianization which, until this point, seems to have been fairly speaceful. Such a view of the late antique process of Christianization tends to ignore, however, that, far from continuing in the footsteps of the powerless Judaeo-Christian minority of the first two centuries CE, late antique Christianity became an increasingly powerful tool of Roman and post-Roman politics that exerted a high degree of structural violence. This is not the place to discuss if either the Muslim subjection of the greater parts of the Mediterranean and the Middle East in the seventh and eighth centuries, or the structural violence exerted by the Muslim elites ruling after this process of subjection, were smore violent than the late antique and early medieval process of Christianization. It seems worthwhile to note, however, that in the longue durée of approximately 1300 years of Christian and Muslim conquest and religious integration, the expanding Christian power of the Norman-Staufen-Angevin Mezzogiorno, the Reconquista and the Spanish conquest of Central and Southern America tended to speak the language of religious conformity, whereas Islamic regimes expanding to subsaharan Africa, India and Malaysia, tended to insist, if in power, on a more or less rigid sociopolitical and religious hierarchy that ensured Muslim sovereignty. In both cases, physical and structural violence played an important role in establishing and maintaining the respective system. 
The degree to which both systems inspired each other is the topic of a huge debate that covers various fields of expertise. These range from the relationship between late antique Christian and early Islamic theology, ${ }^{181}$ Andalusian and troubadour poetry, ${ }^{182}$ the Islamic concept of jihād and the Christian concept of crusades, ${ }^{183}$ the Islamic ribät and the Christian military orders ${ }^{184}$ to that between the Islamic madrasa and the European-Christian university. ${ }^{185}$ In all these cases, prominent scholars have either endorsed or questioned the idea that a ımigration of ideas In most cases, however, it seems difficult to arrive at a final conclusion: in each case, the parallels as well as the differences are striking enough to maintain the conscientious scholar in a precarious and constantly oscillating balance of simultaneously endorsing and refuting the prevalent views in question - a problem apparent to everyone engaging with Jörg Feuchter's, Friedhelm Hoffmann's and Bee Yun's edited volume Cultural Transfers in Dispute. ${ }^{186}$

At the end of his argument that Charlemagne's forced conversion of the Saxons was inspired by the Islamic concept of jiha $\bar{d}$ and religious hierarchization, Yitzhak Hen rightly asks scholars to question their »bold tendency to dismiss instantly any Muslim influence on the cultural, religious, and political history of early medieval Francia «, ${ }^{187}$ an assertion with which most accomplished scholars in the field of Andalusian-Carolingian relations, including Abdurrahman Ali El-Hajji, Philippe Sénac and others, would probably agree. If Charlemagne's forced conversion of the Saxons was inspired by Andalusian Islam, however, is another question. This article has tried to show that, while such an influence cannot be ruled out completely, given the close connections between al-Andalus and the Frankish realm, it does seem highly implausible. In the period under scrutiny, Andalusian Islam was only beginning to establish a more or less clearly structured system of religious hierarchization. The evidence of the Carolingian sources does not allow us to trace the migration of a legal concept of religious hierarchization. Last but not least, the Capitulatio de partibus Saxoniae cannot be regarded as a manifestation of sIslamic thought. Rather, Hen's analysis of the document resorts to hypotheses that seem, all in all, far-fetched, sometimes illogical, and, in many cases, built on false premises, including very ahistorical and imprecise notions of the concepts of jihäd, jizya and dhimma. Every feature of the document can be explained in alternative ways that do not need to resort to an external Islamic inspiration, especially if the preceding history of Christianization is considered. If we still insist on the possibility of a migration of ideas against this backdrop, then we would have to consider that the Muslim conquerors of al-Andalus and the Christian conquerors of Saxony were inspired by the same Zeitgeist, the latter strongly marked the symbolic language of expanding universal truth. Such an interpretation, however, would not be very far from Assmann's and Buc's assessment of the expansionist character of universalist monotheism, a form of belief firmly entrenched in the

181 Rudolph, Westliche Islamwissenschaft im Spiegel muslimischer Kritik, 83-108.

182 Menocal, Close Encounters in Medieval Provence.

183 Noth, Heiliger Krieg und Heiliger Kampf.

184 Feuchter, Islamic Ribat.

185 Makdisi, Rise of Colleges; cf. Geelhaar, Medieval West.

186 Feuchter et al. (eds.), Cultural Transfers in Dispute.

187 Hen, Charlemagne's Jihad, 51.

medieval worlds • No. $3 \cdot 2016 \cdot 3-40$ 
Euromediterranean of the seventh and eighth centuries and manifesting itself in different variations which were built on the same Judaeo-Hellenistic foundations, but not necessarily directly related to each other. ${ }^{188}$ It is at this point that conscientious historical research has to admit that, from a methodological point of view, thinking in plausible alternatives seems more sound than insisting on one, and only one interpretation of a historical constellation. We have to admit, after all, that we cannot see but the tip of the iceberg.

188 Cf. Dawson, Oswald Spengler, 386. 


\section{References}

\section{Primary Sources}

Ahbār mağmū'a, ed./trans. Don Emilio Lafuente y Alcántara (Madrid, 1867).

Alcuinus, Epistolae, ed. Ernst Dümmler, MGH Epp. [4], Epistolae Karolini aevi [2] (Berlin, 1895) 1-481.

Ambrosius, De obitu Theodosii oratio, ed. Otto Faller, CSEL 73/7 (Vienna, 1955) 369-401.

Annales Fuldenses sive Annales regni Francorum orientalis, ed. Georg Heinrich Pertz and Friedrich Kurze, SS rer. Germ. in us. schol. [7] (Hanover, 1891).

Annales Mettenses posteriores, ed. Bernhard von Simson, SS rer. Germ. in us. schol. [10] (Hanover, 1905), 99-106.

Annales Mettenses priores, ed. Bernhard von Simson, SS rer. Germ. in us. schol. [10] (Hanover, 1905), 1-98.

Annales regni Francorum inde ab a. 741 usque ad a. 829 qui dicuntur Annales Laurissenses maiores et Einhardi, ed. Georg Heinrich Pertz and Friedrich Kurze, MGH SS rer. Germ. in us. schol. [6] (Hanover, 1895).

Annales regnum Francorum et Annales Laurissenses maiores qui dicuntur Einhardi, ed. Georg Heinrich Pertz and Friedrich Kurze, SS rer. Germ. [6] (Hanover, 1895).

Augustine of Hippo, Epistula 93 ad Vincentinum donatistam, ed. Aloys Goldbacher, CSEL 34/2 (Vienna, 1898).

Al-Balādhurī, Kitāb futūḥ al-buldān, ed. Michael Jan de Goeje (Leiden, 1886).

Capitulatio de partibus Saxoniae, ed. Alfred Boretius, MGH Capitularia regum Francorum [1] (Hanover, 1883) 68-70.

Carmen de sinodo Ticinensi, ed. Ludwig Bethmann, MGH SS rer. Lang. (Hanover, 1878) 190-191. Chronicarum quae dicuntur Fredegarii scholastici libri IV cum continuationibus, ed. Bruno Krusch, MGH Script. rer. Merov. [2] (Hanover, 1888) 1-194.

Chronicon Moissiacense, ed. Georg Heinrich Pertz, MGH SS in folio [1](Hanover, 1826) 282313.

Codex Theodosianus, ed. Theodor Mommsen and Paul Meyer (Berlin, 1905).

Constitutio de Hispanis in Francorum regnum profugus prima, ed. Alfredus Boretius, MGH Leges, Capitularia regum Francorum [1], no. 132 (Hanover, 1883) 261-63.

Constitutio Hludowici de Hispanis secunda, ed. Alfredus Boretius, MGH Leges, Capitularia regum Francorum [1], no. 133 (Hanover, 1883) 263.

Continuatio hispana, ed. Theodor Mommsen, MGH Auct. Ant. [11] (Berlin, 1894) 323-369.

Al-Ḍabbì, Kitäb bughyāt al-multamis fì tärïkh rijäl ahl al-Andalus, ed. Francisco Codera and Julián Ribera (Madrid, 1885).

De conversione Saxonum carmen, ed. Ernst Dümmler, MGH Poetae [1] (Berlin, 1881) 380-381.

Diploma 179, ed. Engelbert Mühlbacher, MGH DD, Diplomata Karolinorum [1] (Hanover, 1906) 241-242.

Einhardus, Vita Karoli Magni, ed. Georg Heinrich Pertz, Georg Waitz and Otto Holder-Egger, MGH SS rer. Germ. in us. schol. [25] (6th edition) (Hanover, 1911).

Einhartus, Epistolae, ed. Karl Hampe, MGH Epp. [5], Epistolae Karolini aevi [3] (Berlin, 1899) 105-145.

Ermoldus Nigellus, Carmen in honorem Hludowici, ed. Ernst Dümmler, MGH Poetae [2] (Berlin, 1884) 5-79. 
Gesta abbatum Fontanellensium, ed. Samuel Loewenfeld, MGH SS rer. Germ. in us. schol. [28] (Hanover, 1886).

Gesta episcoporum Autissiodorensium, ed. Georg Waitz, MGH Script. in fol. [13] (Hanover, 1881) 393-403.

Gregorius Turonensis, Libri historiarum decem, ed. Bruno Krusch and Wilhelm Levison, MGH SS rer. Merov. [1,1] (Berlin, 1951).

Al-Ḥimyarī, Kitāb al-raw d al-mi țār fì khabar al-aqțār, ed. Iḥsān 'Abbās (Beirut, 1975).

Ibn 'Abd al-Ḥakam, Futūh Miṣr wa-ahbāruhā, ed. Charles Torrey (New Haven, 1922; repr. Cairo, 1999).

Ibn al-Khațīb, Al-Ihāța fì akhbār Gharnāța, ed. Muḥammad 'Abd Allāh 'Inān, 4 vols. (Cairo 1973-1977).

Ibn al-Qūṭiyya, Tārìkh iftitāḥ al-Andalus, ed. Ibrāhīm al-Ibyārī (Beirut, 1989).

Ibn Ḥayyān, Al-sufr al-thānī min kitāb al-muqtabis [II-1], ed. Maḥmūd Makkī (Riyadh, 2003)

Ibn 'Idhārī al-Marrākushī, Kitāb al-bayān al-mughrib, ed. Georges Séraphin Colin and Évariste Lévi-Provençal, 3 vols. (Beirut, 1980-83).

Ibn Khaldūn, Tārīkh, ed. Suhayl Zakkār, Khalīl Shahāda, 8 vols., (Beirut, 2000-2001).

Iohannis abbas s. Arnulfi, Vita Iohannis abbatis Gorziensis, ed. Georg Heinrich Pertz, MGH SS in fol. [4], (Hanover, 1841), 335-377.

Isidorus Hispalensis, Historia Gothorum Wandalorum Sueborum ad a. 624, ed. Theodor Mommsen, MGH AA [11] (Berlin, 1894), 241-303.

Al-Khushanī, Kitāb al-quḍāt bi-Qurțuba/Historia de los jueces de Córdoba, ed./trans. Julián Ribera (Madrid, 1914).

Liber pontificalis, ed. Louis Duchesne, 3 vols. (Paris, 1955-57).

Mālik b. Anas, Al-muwațtā' bi-riwāyatihi Yahyā al-Laythī, ed. Abū Usāma Salīm bin 'Abd alHadālī as-Salafì (Alexandria, 2003).

Opus Caroli regis contra synodum (Libri Carolini), ed. Ann Freemann and Paul Meyvaert, MGH Conc. [2], Suppl. 1 (Hanover, 1998).

Paulus Diaconus, Historia Langobardorum, ed. Ludwig Bethmann and Georg Waitz, SS rer. Germ. in us. schol. [48] (Hanover, 1878) 69-242.

Praeceptum pro Hispanis (11 June 844), ed. Alfredus Boretius, MGH Leges, Capitularia regum Francorum [2], 256 (Hanover, 1897) 259.

Praeceptum pro Hispanis (2 April 812), ed. Alfredus Boretius, MGH Leges, Capitularia regum Francorum [1], 76 (Hanover, 1883) 169.

Rodulfus Glaber, Historiarum libri quinque/The Five Books of the Histories, ed./trans. John France (Oxford, 2002).

Theodulfus Aurelianensis, Carmina, ed. Ernst Dümmler, MGH Poetae latini aevi carolini [1] (Berlin, 1881) 437-568.

Al-'Udhrī, Tarșī' al-akhbār, ed. 'Abd al-'Azīz al-Ahwānī (Madrid, 1965).

\section{Secondary Literature}

Abun-Nasr, Jamil M., A History of the Maghrib in the Islamic Period (Cambridge, 1987).

Anton, Hans Hubert, Der König und die Reichskonzilien im westgotischen Spanien, Historisches Jahrbuch 92 (1972) 257-281.

Assmann, Jan, The Mosaic Distinction: Israel, Egypt, and the Invention of Paganism, Representations 56 (1996) 48-67. 
Assmann, Jan, Die Mosaische Unterscheidung oder der Preis des Monotheismus (Vienna, 2003).

Bade, Norman, Vorstellungen vom Islam und den Sarazenen in der >Vita Hludowici Imperatoris` und den `Annales Bertiniani<: Möglichkeiten und Grenzen einer terminologischen Untersuchung, in: Anna Aurast and Hans-Werner Goetz (eds.), Die Wahrnehmung anderer Religionen im früheren Mittelalter: Terminologische Probleme und methodische Ansätze (Berlin, 2012) 89-120.

Bade, Norman, Die christlich-abendländische Wahrnehmung vom Islam und von den Muslimen im Spiegel historiographischer Werke des frühen Mittelalters: Eine Studie über die kontextbedingte Entstehung eines religiösen Feindbildes (Hamburg, 2015).

Basset, René, and Pellat, Charles, Berbers. Religion, Encyclopaedia of Islam 2 (Leiden, 1960) 1178-1179.

Becher, Matthias, Gewaltmission: Karl der Große und die Sachsen, in: Christoph Stiegemann, Martin Kroker and Wolfgang Walther (eds.), Credo. Christianisierung Europas im Mittelalter (Petersberg, 2013).

Borgolte, Michael, Der Gesandtenaustausch der Karolinger mit den Abbasiden und mit den Patriarchen von Jerusalem (Munich, 1976).

Brett, Michael, The Arab Conquest and the Rise of Islam in North Africa, in: John D. Fage (ed.), The Cambridge History of Africa, vol. 2 (Cambridge, 1978) 505-522.

Brett, Michael, and Fentress, Elisabeth, The Berbers (Oxford, 1996).

Brown, Peter, The Rise of Western Christendom: Triumph and Diversity, AD 200-100o (Cambridge/Mass., 1996).

Brunhölzl, Franz, Geschichte der lateinischen Literatur, vol. 1: Von Cassiodor bis zum Ausklang der karolingischen Erneuerung (Munich, 1996).

Buc, Philippe, Holy War, Martyrdom, and Terror: Christianity, Violence, and the West (Philadelphia, 2015).

Cahen, Claude, Djizya, in: Encyclopaedia of Islam 2, vol. 2 (Leiden, 1965) 559-62.

Cahen, Claude, Kharādj, in: Encyclopaedia of Islam 2, vol. 6 (Leiden, 1978) 1030-34.

Cardelle de Hartmann, The Textual Transmission of the Mozarabic Chronicle of 754, Early Medieval Europe 8/1 (1998) 13-29.

Carra de Vaux, Bernard, Schacht, Joseph and Goichon, Anne-Marie, Hadd, in: Encyclopaedia of Islam 2, vol. 3 (Leiden, 1981) 20-22.

Chalmeta Gendrón, Pedro, Ḳūmis, in: Encyclopedia of Islam 2, vol. 5 (Leiden, 1986) 376.

Chalmeta Gendrón, Pedro, Invasión e islamización: La sumisión de Hispania y la formación de al-Andalus (Jaén, 2003).

Clarke, Nicola, The Muslim Conquest of Iberia: Medieval Arabic Narratives (London, 2012).

Cohen, Mark R., What was the Pact of 'Umar? A Literary-Historical Study, Jerusalem Studies in Arabic and Islam 23 (1999) 100-157.

Constable, Olivia Remie, Trade and Traders in Muslim Spain: The Commercial Realignment of the Iberian Peninsula, 900-1500 (Cambridge, 1996).

Constable, Olivia Remie (ed.), Medieval Iberia: Readings from Jewish, Christian and Muslim Sources (Philadelphia, 1997).

Crone, Patricia, Medieval Islamic Political Thought (2nd edition), (Edinburgh, 2005).

Daniel, Norman, Islam and the West: The Making of an Image (Edinburgh, 1960).

Dawson, Christopher, Oswald Spengler and the Life of Civilizations, in: Christopher Dawson and John J. Mulloy (eds.), The Dynamics of World History (London, 1956) 374-389.

Dennet, Daniel C., Conversion and the Poll-Tax in Early Islam (Cambridge/Mass., 1950). 
Depreux, Philippe, Les préceptes pour les Hispani de Charlemagne, Louis le Pieux et Charles le Chauve, in: Philippe Sénac (ed.), Aquitaine - Espagne (viie-xiiie siècles) (Poitiers, 2001) 19-38.

Devroey, Jean-Pierre, L'introduction de la dîme obligatoire en Occident: entre espaces ecclésiaux et territoires seigneuriaux à l'époque carolingienne, in: Lauwers, La dîme, 87-106.

Dhanun Taha, Abdulwahid, The Muslim Conquest and Settlement of North Africa and Spain (London, 1989).

Dhū'n-Nūn Ṭāha, 'Abd al-Wāhid, Importance des voyages scientifiques entre l'Orient et l'Andalus, Revue de l'Occident musulman et de la Méditerranée 40 (1985) 39-44.

Donner, Fred M., The Islamic Conquests, in: Youssef M. Choueiri (ed.), A Companion to the History of the Middle East (Malden, 2005) 28-51.

Dumézil, Bruno, Les racines chrétiennes de l'Europe: Conversion et liberté dans les royaumes barbares Ve-VIIIe siècles (Paris, 2006).

Ehlers, Caspar, Jihad oder Parusieverzögerung? Zur heilsgeschichtlichen Bedeutung eines Raumes außerhalb des Römischen Reiches, Rechtsgeschichte 23 (2015) 151-173.

El-Hajji, Abdurrahman Ali, Political Relations of Andalusian Rebels with the Franks During the Umayyad Period (A.H. 138-366/ A.D. 755-976), Islamic Quarterly 12 (1968), 56-70.

El-Hajji, Abdurrahman Ali, Andalusian Diplomatic Relations with Western Europe During the Umayyad Period (A.H. 138-366 / A.D. 755-976): An Historical Survey (Beirut, 1970).

Erdmann, Carl, Die Entstehung des Kreuzzugsgedankens (repr. of 1935), (Darmstadt, 1972).

Fattal, Antoine, Le statut légal des non-musulmans en pays d'Islam (Beirut, 1955).

Feuchter, Jörg, The Islamic Ribat - A Model for the Christian Military Orders? Sacred Violence, Religious Concepts and the Invention of a Cultural Transfer, in: Heike Bock, Jörg Feuchter, and Michi Knecht (eds.), Religion and its Other: Secular and Sacral Concepts and Practices in Interaction (Frankfurt, 2008) 115-141.

Feuchter, Jörg, Hoffmann, Friedhelm and Yun, Bee (eds.), Cultural Transfers in Dispute: Representations in Asia, Europe and the Arab World since the Middle Ages (Frankfurt, 2011).

Fierro, Isabel, The Introduction of hadith in al-Andalus, Der Islam 66 (1989) 68-93.

Fierro, Isabel, El Alfaquí Beréber Yahyyā b. Yaḥyā al-Layțī (m. 234/848), »el inteligente de al-Andalus«, in: María Luisa Avila and Manuela Marín (eds.), Estudios onomástico-biográficos de al-Andalus 8: Biografías y género biográfico en el occidente islámico (Madrid, 1997) 269-344.

Fletcher, Richard, The Conversion of Europe: From Paganism to Christianity 371-1386 (London, 1998).

Freemann, Ann, Theodulf of Orléans: Charlemagne's Spokesman against the Second Council of Nicaea (Aldershot, 2003).

Friedman, Yohanan, Freedom and Coercion in Islam: Interfaith Relations in the Muslim Tradition (Cambridge, 2003).

Geary, Patrick, Judicial Violence and Torture in the Carolingian Empire, in: Ruth Mazo Karras, Joel Kaye, and E. Ann Matter (eds.), Law and the Illicit in Medieval Europe (Philadelphia, 2008) 79-88.

Geelhaar, Tim, Did the Medieval West Receive a >Complete Model of Education from Classical Islam? Reconsidering George Makdisi and his Thesis, in: Jörg Feuchter, Friedhelm Hoffmann and Bee Yun (eds.), Cultural Transfers in Dispute. Representations in Asia, Europe and the Arab World since the Middle Ages (Frankfurt, 2011) 61-84.

Geelhaar, Tim, Christianitas. Eine Wortgeschichte von der Spätantike bis zum Mittelalter (Göttingen, 2015). 
Gillard, Xavier and Sénac, Philippe, À propos de quelques Hispani, Cahiers de civilisation médiévale 186 (2004) 163-169.

Girgensohn, Joseph, Prudentius und die Bertinianischen Annalen (Riga, 1875).

Goetz, Hans-Werner, Sarazenen als Fremde? Anmerkungen zum Islambild in der abendländischen Geschichtsschreibung des frühen Mittelalters, in: Benjamin Jokisch, Ulrich Rebstock and Lawrence I. Conrad (eds.), Fremde, Feinde und Kurioses (Berlin, 2009) 39-66.

Goetz, Hans-Werner, Die Wahrnehmung anderer Religionen und christlich-abendländisches Selbstverständnis im frühen und hohen Mittelalter, vol. 1 (Berlin, 2013).

Hen, Yitzhak, Charlemagne's Jihad, Viator 37 (2006) 33-52.

Hernández Juberías, Julia, La península imaginaria. Mitos y leyendas sobre al-Andalus (Madrid, 1996).

Hirschfeld, Haim Z., The Problem of the Judaized Berbers, Journal of African History 4/3 (1963) 313-339.

Kahl, Hans-Dietrich, Karl der Große und die Sachsen. Stufen und Motive einer historischen 'Eskalation<, in: Herbert Ludat and Rainer Christoph Schwinges (eds.), Politik, Gesellschaft, Geschichtsschreibung. Giessener Festgabe für Frantisek Graus (Cologne, 1982) 49-130.

Kallfelz, Wolfgang, Nichtmuslimische Untertanen im Islam: Grundlage, Ideologie und Praxis der Politik frühislamischer Herrscher gegenüber ihren nichtmuslimischen Untertanen mit besonderem Blick auf die Dynastie der Abbasiden (749-1248) (Wiesbaden, 1995).

Kedar, Benjamin Z., Crusade and Mission: European Approaches to the Infidels (Princeton, 1984).

Kennedy, Hugh, The Great Arab Conquests: How the Spread of Islam Changed the World we Live in (Philadelphia, 2007).

Khadduri, Majid, War and Peace in the Law of Islam (Baltimore, 1955).

King, Paul David, Law and Society in the Visigothic Kingdom (Cambridge, 1972).

König, Daniel, Christliche sHelden` und Gewalt, in: Michael Borgolte, Juliane Schiel, Bernd Schneidmüller and Annette Seitz (eds.), Mittelalter im Labor: Die Mediävistik testet Wege zu einer transkulturellen Europawissenschaft (Berlin, 2008) 483-492.

König, Daniel, Bekehrungsmotive: Untersuchungen zum Christianisierungsprozess im Römischen Westreich und seinen romanisch-germanischen Nachfolgern (Husum, 2008).

König, Daniel G., Öffentliche religiöse Auseinandersetzungen unter Beteiligung spätantik-frühmittelalterlicher Höfe: Versuch einer Typologie, in: Matthias Becher and Alheydis Plassmann (eds.), Streit am Hof im frühen Mittelalter (Göttingen, 2011) 17-44.

König, Daniel G., Arabic-Islamic Views of the Latin West: Tracing the Emergence of Medieval Europe (Oxford, 2015).

Körntgen, Ludger, Heidenkrieg und Bistumsgründung: Glaubensverbreitung als Herrscheraufgabe bei Karolingern und Ottonen, in: Andreas Holzem (ed.), Krieg und Christentum: Religiöse Gewalttheorien in der Kriegserfahrung des Westens (Paderborn, 2009) 281-304.

Kossmann, Maarten, The Arabic Influence on Northern Berber (Leiden, 2013).

Lévi- Provençal, Évariste, Histoire de l'Espagne musulmane, vol. 1: La Conquête et l'émirat hispano-umaiyade (710-912) (Paris, Leiden, 1950).

Lévi-Provençal, Évariste, Un recit de la conquête de l'Afrique du Nord, Arabica 1 (1954) 35-43.

Levy-Rubin, Milka, Non-Muslims in the Early Islamic Empire: From Surrender to Coexistence (Cambridge, 2011).

Maier, Hans, Compelle intrare. Rechtfertigungsgründe für die Anwendung von Gewalt zum Schutz und zur Ausbreitung des Glaubens in der Theologie des abendländischen Christentums, in: Klaus Schreiner (ed.), Heilige Kriege. Religiöse Begründungen militärischer Gewaltanwendung: Judentum, Christentum und Islam im Vergleich (Munich, 2008) 55-69. 
Makdisi, George, The Rise of Colleges. Institutions of Learning in Islam and the West (Edinburgh, 1981).

Makkī, Maḥmūd, Ensayo sobre las aportactiones orientales en la España musulmana, Revista del instituto egipcio de estudios islámicos en Madrid 9-10 (1961-62) 65-92.

Manzano Moreno, Eduardo, Conquistadores, emires y califas: Los omeyas y la formación de al-Andalus (Barcelona, 2011).

McCormick, Michael, Pippin III, the Embassy of al-Mansur, and the Mediterranean World, in: Matthias Becher and Jörg Jarnut (eds.), Der Dynastiewechsel von 751: Vorgeschichte, Legitimationsstrategien, Erinnerung (Paderborn, 2004) 221-241.

McKenna, Stephen, Paganism and Pagan Survivals in Spain up to the Fall of the Visigothic Kingdom (Washington, 1938).

Menocal, María Rosa, Close Encounters in Medieval Provence: Spain's Role in the Birth of Troubadour Poetry, Hispanic Review 49/1 (1981) 43-64.

Miller, Daniel E., From Catalogue to Codes to Canon: The Rise of the Petition to 'Umar among Legal Traditions Governing non-Muslims in Medieval Islamicate Societies, PhD-thesis (University of Missouri-Kansas City, 2000).

Mohr, Andreas, Das Wissen über den Anderen: Zur Darstellung fremder Völker in den Quellen der Karolingerzeit (Münster, 2005).

Molina, Luis, Tudmir, Encyclopaedia of Islam 2, vol. 10 (Leiden 2000) 584-85.

Nelson, Janet L., Religion and Politics in the Reign of Charlemagne, in: Ludger Körnten and Dominik Waßenhoven (eds.), Religion und Politik im Mittelalter: Deutschland und England im Vergleich (Berlin, 2013) 17-29.

Norris, Harry T., The Berbers in Arabic Literature (London, 1982).

Noth, Albrecht, Heiliger Krieg und Heiliger Kampf in Islam und Christentum: Beiträge zur Vorgeschichte und Geschichte der Kreuzzüge, Bonner historische Forschungen 28 (Bonn, 1966).

Noth, Albrecht, Die literarisch überlieferten Verträge der Eroberungszeit als historische Quellen für die Behandlung der unterworfenen Nicht-Muslime durch ihre neuen muslimischen Oberherren, in: Tilman Nagel (ed.), Studien zum Minderheitenproblem im Islam, vol. 1 (Bonn, 1973) 282-314.

Noth, Albrecht, Abgrenzungsprobleme zwischen Muslimen und Nicht-Muslimen: Die >Bedingungen 'Umars` (aš-šurūṭ al-'umariyya) unter einem anderen Aspekt gelesen, Jerusalem Studies in Arabic and Islam 9 (1987) 290-315.

Noth, Albrecht, Der frühe Islam, in: Ulrich Haarmann (ed.), Geschichte der arabischen Welt (Munich, 1987) 11-100.

O'Callaghan, Joseph F., A History of Medieval Spain (Ithaca, 1983).

Padberg, Lutz E. von, Die Christianisierung Europas im Mittelalter (Stuttgart, 1998).

Peña Martín, Salvador (ed.), Iraq y al-Andalus: Oriente en el Occidente islámico (Almería, 2009). Planhol, Xavier de, Minorités en Islam: Géographie politique et sociale (Paris, 1997).

Prinz, Friedrich, Klerus und Krieg im früheren Mittelalter: Untersuchungen zur Rolle der Kirche beim Aufbau der Königsherrschaft (Stuttgart, 1971).

Puza, R., Zehnt. I. Allgemeine Darstellung des Kirchenzehnten, Lexikon des Mittelalters 9 (Munich, 1998) 499-501.

Rouighi, Ramzi, The Berbers of the Arabs, Studia Islamica Nouvelle Édition 1 (2011) 67-101.

Rudolph, Ekkehard, Westliche Islamwissenschaft im Spiegel muslimischer Kritik: Grundzüge und aktuelle Merkmale einer innerislamischen Diskussion (Berlin, 1991). 
Russell, James C., The Germanization of Early Medieval Christianity: A Sociohistorical Approach (Oxford, 1996).

Safran, Janina M., Defining Boundaries in al-Andalus: Muslims, Christians and Jews in Islamic Iberia (Ithaca, 2013).

Schacht, Joseph, The Origins of Muhammadan Jurisprudence (Oxford, 1950).

Schacht, Joseph, al-Awza ī, Encyclopaedia of Islam 2, vol. 1 (Leiden, 1960) 772-773.

Schäferdiek, Knut, Die Anfänge des Christentums bei den Goten und der sog. gotische Arianismus, Zeitschrift für Kirchengeschichte 112 (2001) 295-310.

Schäferdiek, Knut, Gab es eine gotisch-arianische Mission im süddeutschen Raum? (1982), in: Knut Schäferdiek, Winrich A. Löhr and Hanns Christof Brennecke (eds.), Schwellenzeit: Beiträge zur Geschichte des Christentums in Spätantike und Frühmittelalter (Berlin, 1996) 203-222.

Schubert, Ernst, Die Capitulatio de partibus Saxoniae, in: Dieter Brosius, Christine van der Haevel, Ernst Hinrichs and Hajo van Lengen (eds.), Geschichte in der Region: Zum 65. Geburtstag von Heinrich Schmidt (Hanover, 1993) 5-11.

Sénac, Philippe, Musulmans et Sarrasins dans le sud de la Gaule du VIII au XIe siècle (Paris, 1980).

Sénac, Philippe, L'Occident face à l'Islam. L'image de l'Autre (Paris, 1983).

Sénac, Philippe, Les Carolingiens et al-Andalus (VIII -IX ${ }^{\mathrm{e}}$ siècles) (Paris, 2002).

Shatzmiller, Maya, Labour in the Medieval Islamic World (Leiden, 1994).

Southern, Richard, Western Views of Islam in the Middle Ages (Cambridge/Mass., 1962).

Stone, Rachel, Morality and Masculinity in the Carolingian Empire (Cambridge, 2012).

Tolan, John, Saracens: Islam in the Medieval European Imagination (New York, 2002).

Toneatto, Valentina, Dîme et construction de la communauté chrétienne, des Pères de l'église aux Carolingiens (IV ${ }^{\mathrm{e}}$-VIII ${ }^{\mathrm{e}}$ siècles), in: Lauwers, Michel (ed.), La dîme, l'église et la société féodale (Turnhout, 2012) 65-86.

Tritton, Arthur Stanley, The Caliphs and their non-Muslim Subjects: A Critical Study of the Covenant of 'Umar (London, 1930).

Voegelin, Eric, Order and History, vol. 1: Israel and Revelation (2nd edition), (Ohio, 1958).

Vogt, Joseph, Zur Religiosität der Christenverfolger im Römischen Reich, Sitzungsberichte der Heidelberger Akademie der Wissenschaften, Philosophisch-historische Klasse 1962/1 (Heidelberg, 1962).

Watt, William Montgomery, and Cachia, Pierre, A History of Islamic Spain (repr. of 1965), (Piscataway, 2008).

Wolf, Kenneth Baxter, Conquerors and Chroniclers of Early Medieval Spain (2nd edition), (Liverpool 1999).

Wood, Ian, The Missionary Life. Saints and the Evangelisation of Europe, 400-1050 (Harlow, 2001).

Ye'or, Bat, The Dhimmi. Jews and Christians under Islam (London, 1985). 